\title{
A multiscale approach to estimate the cellular diffusivity during food
}

\section{drying}

\author{
Zachary G. Welsh ${ }^{\mathrm{a}}$, Md Imran H. Khan ${ }^{\mathrm{a}, \mathrm{b}}$, Matthew J. Simpson ${ }^{\mathrm{c}}$ and M. A. Karim*a \\ ${ }^{a}$ Mechanical, Medical and Process Engineering, Queensland University of Technology, \\ Brisbane, Australia \\ ${ }^{\mathrm{b}}$ Department of Mechanical Engineering, Dhaka University of Engineering \& Technology, \\ Gazipur, Bangladesh \\ c School of Mathematical Sciences, Queensland University of Technology, \\ Brisbane, Australia
}

Corresponding author: Azharul Karim, Queensland University of Technology 2 George Street, QLD 4000 Australia, azharul.karim@qut.edu.au

\begin{abstract}
:
Theoretical models for food drying commonly utilize an effective diffusivity solved through curve fitting based on experimental data. This creates models with limited predictive capabilities. Multiscale modeling is one approach which can help transition to a more physicsbased model minimizing the empirical information required while improving a model's predictive capabilities. However, to enable an accurate scaling operation, multiscale models require diffusivity at a fine scale (microscale). Measuring these properties is experimentally costly and time consuming as they are often temperature and/or moisture dependent. This research conducts an inverse analysis on a multiscale homogenization food drying model to deduce the temporal diffusivity of intracellular water. A representation of the real cellular water breakdown was considered and appropriate assumptions to represent its cellular heterogeneity, in relation to time, were investigated. The work uncovered that a linear decrease in intracellular
\end{abstract}


water content could be assumed and thus a function for its diffusivity was developed. The proposed function is in terms of sample temperature and intracellular water content opening the possibilities to be applied to various food materials.

Keywords: multiscale modeling, cellular diffusivity, homogenization, food drying, temporal

\section{Nomenclature}

\begin{tabular}{|c|c|}
\hline Abbreviations & \\
\hline FW & Free water \\
\hline ICW & Intracellular water \\
\hline NMR & Nuclear Magnetic resonance \\
\hline Symbols & \\
\hline$C$ & Macroscale instantaneous moisture concentration $\left(\mathrm{mol} \mathrm{m}^{-3}\right)$ \\
\hline$c$ & Microscale concentration $\left(\mathrm{mol} \mathrm{m}^{-3}\right)$ \\
\hline$c_{p}$ & Specific heat of apple tissue $\left(\mathrm{J} \mathrm{kg}^{-1} \mathrm{~K}^{-1}\right)$ \\
\hline$c_{p \text { air }}$ & Specific heat of air $\left(\mathrm{kJ} \mathrm{kg}^{-1} \mathrm{~K}^{-1}\right)$ \\
\hline$D$ & Cellular diffusivity $\left(\mathrm{m}^{2} \mathrm{~s}^{-1}\right)$ \\
\hline $\mathrm{D}$ & Binary mass diffusivity $\left(\mathrm{m}^{2} \mathrm{~s}^{-1}\right)$ \\
\hline$\overline{D_{\text {eff }}}$ & Effective moisture diffusivity $\left(\mathrm{m}^{2} \mathrm{~s}^{-1}\right)$ \\
\hline$\overline{\overline{D_{e f f}}}$ & Average diffusivity $\left(\mathrm{m}^{2} \mathrm{~s}^{-1}\right)$ \\
\hline$D_{F W}$ & Diffusivity of free water $\left(\mathrm{m}^{2} \mathrm{~s}^{-1}\right)$ \\
\hline$D_{\text {ICW }}$ & Diffusivity of intracellular water $\left(\mathrm{m}^{2} \mathrm{~s}^{-1}\right)$ \\
\hline$D_{o}$ & Integration constant $\left(\mathrm{m}^{2} \mathrm{~s}^{-1}\right)$ \\
\hline
\end{tabular}




\begin{tabular}{|c|c|}
\hline$E_{a}$ & Activation energy $\left(\mathrm{J} \mathrm{mol}^{-1}\right)$ \\
\hline$h_{f g}$ & Latent heat of evaporation $\left(\mathrm{J} \mathrm{kg}^{-1}\right)$ \\
\hline$h_{m}$ & Mass transfer coefficient $\left(\mathrm{m} \mathrm{s}^{-1}\right)$ \\
\hline$h_{T}$ & Heat transfer coefficient $\left(\mathrm{W} \mathrm{m}^{-2} \mathrm{~K}^{-1}\right)$ \\
\hline$k$ & Thermal conductivity of apple tissue $\left(\mathrm{W} \mathrm{m} \mathrm{m}^{-1} \mathrm{~K}^{-1}\right)$ \\
\hline$k_{\text {air }}$ & Thermal conductivity of air $\left(\mathrm{W} \mathrm{m}^{-1} \mathrm{~K}^{-1}\right)$ \\
\hline$L_{c}$ & Characteristic length (m) \\
\hline$M_{0}$ & Initial moisture content $\left(\mathrm{kg} \mathrm{kg}^{-1}\right.$ dry bases $)$ \\
\hline$M_{0 w b}$ & Initial wet basis moisture content $\left(\mathrm{kg} \mathrm{kg}^{-1}\right.$ wet bases $)$ \\
\hline$M_{d b}$ & Moisture content dry basis ( $\mathrm{kg} \mathrm{kg}^{-1}$ dry bases) \\
\hline $\bar{M}_{d b, \exp }$ & Average experimental moisture content $\left(\mathrm{kg} \mathrm{kg}^{-1}\right.$ dry bases $)$ \\
\hline$\overline{\bar{M}}_{d b, n u m}$ & Average predicted moisture content $\left(\mathrm{kg} \mathrm{kg}^{-1}\right.$ dry bases $)$ \\
\hline$M_{e}$ & Equilibrium moisture content ( $\mathrm{kg} \mathrm{kg}^{-1}$ dry bases) \\
\hline$M_{w}$ & Molar mass of water $\left(\mathrm{kg} \mathrm{mol}^{-1}\right)$ \\
\hline $\mathbf{n}$ & Unit vector normal to the boundary \\
\hline$N u_{L c}$ & Nusselt number \\
\hline$P r$ & Prandtl number \\
\hline & Vapor air pressure of ambient air $(\mathrm{Pa})$ \\
\hline$p_{v}$ & Equilibrium vapor pressure $(\mathrm{Pa})$ \\
\hline$p_{v \text { sat }}$ & Saturated vapor pressure of water $(\mathrm{Pa})$ \\
\hline$R$ & Universal gas constant $\left(\mathrm{J} \mathrm{mol}^{-1} \mathrm{~K}^{-1}\right)$ \\
\hline$r, z$ & Macroscale spherical coordinates (m) \\
\hline$R e_{L c}$ & Reynold's Number \\
\hline Sc & Schmidt Number \\
\hline
\end{tabular}




\begin{tabular}{|c|c|}
\hline$S h_{L c}$ & Sherwood number \\
\hline$t$ & Time (s) \\
\hline$T$ & Macroscale instantaneous Temperature (K) \\
\hline$T_{0}$ & Initial sample temperature $(\mathrm{K})$ \\
\hline$T_{\text {air }}$ & Drying air temperature $(\mathrm{K})$ \\
\hline$\overline{T_{S}}$ & Sample temperature $(\mathrm{K})$ \\
\hline$u_{1}$ and $u_{2}$ & Corrective factors \\
\hline$v$ & Air velocity $\left(\mathrm{m} \mathrm{s}^{-1}\right)$ \\
\hline$W C_{I C W}$ & Intracellular water content \\
\hline$x, y$ & Microscale cartesian coordinates (m) \\
\hline \multicolumn{2}{|l|}{ Greek symbols } \\
\hline$\beta$ & Coefficients \\
\hline$\mu_{\text {air }}$ & Viscosity of air $\left(\mathrm{kg} \mathrm{m}^{-1} \mathrm{~s}^{-1}\right)$ \\
\hline$\rho$ & Density of apple tissue $\left(\mathrm{kg} \mathrm{m}^{-3}\right)$ \\
\hline$\rho_{\text {air }}$ & Density of air $\left(\mathrm{kg} \mathrm{m}^{-3}\right)$ \\
\hline$\rho_{w}$ & Density of water $\left(\mathrm{kg} \mathrm{m}^{-3}\right)$ \\
\hline$v_{\text {air }}$ & Kinematic viscosity of air $\left(\mathrm{m}^{2} \mathrm{~s}^{-1}\right)$ \\
\hline$\omega$ & Area of the microscale domain $\left(\mathrm{m}^{2}\right)$ \\
\hline
\end{tabular}

\section{Introduction}

Drying is one of the most dominant food preservations and processing techniques. The demand for dried food products has significantly increased over the last decades driving a fastgrowing global food drying industry. Although various drying methods, including drying with renewable energy (Bahammou et al., 2019; Bahammou et al., 2020), have been developed, hot 
air or convective drying is still being widely used by industry due to its simplicity. However, convective drying is an energy intensive lengthy process which can cause deterioration of a product's final quality (Pham et al., 2019). Additionally, drying is a complex multiphysics problem which involves simultaneous heat, mass, and momentum transport processes with continuous phase change (Khan, Joardder, Kumar, \& Karim, 2018). In order to address these complex problems and design optimal and effective food drying systems, fundamental understanding of the transport process needs to be developed.

Physics-based mathematical modeling can provide deep insight into drying, and as such, many researchers have developed models in an attempt to simulate the complex drying process spanning spatial and temporal dimensions (Khan, Welsh, Gu, Karim, \& Bhandari, 2020). However, food materials are complex and multiscale in nature. Plant-based food materials are structurally heterogeneous with moisture distributed throughout the various cellular environments of the material (Rahman, Gu, \& Karim, 2018; Rahman, Joardder, \& Karim, 2018). It has been found that the largest proportion of water (around $80 \%$ ) is located within intracellular spaces (inside cell vacuole), known as intracellular water (ICW), whereas the remainder of the water is located within the intercellular and cell wall environments (Khan, Wellard, Nagy, Joardder, \& Karim, 2016). During drying, cellular water can migrate from its cellular compartment to the surrounding environments through various migration pathways. Specifically, ICW migrates from cell to a neighboring cell via diffusion and from cell to intercellular spaces through periodic cell rupturing (Khan, Wellard, Nagy, Joardder, \& Karim, 2017). Most existing physics-based models have been developed to investigate drying at the macroscale (tissue scale) (Kumar, Joardder, Farrell, Millar, \& Karim, 2016), where the structure of the material is approximated as a representative elementary volume (REV) (Whitaker, 1977), neglecting to consider the material's dynamic cellular heterogeneity and the migration of ICW (Wang, Chen, \& Mujumdar, 2007). The migration of ICW causes dynamic 
modifications to the materials physical structure and nutritional characteristics effecting the products quality (Pham, Khan, \& Karim, 2020), and therefore needs be considered to accurately predict the drying kinetics and optimize the drying processes. To address such a research problem, multiscale modeling has been introduced to the field of food drying (Welsh, Simpson, Khan, \& Karim, 2018).

Multiscale modeling is an approach which can help transition towards a more mechanistic model by considering the dynamic water heterogeneity within the material (Welsh, Khan, \& Karim, 2021). A multiscale model is a series of sub-models which investigate a products behavior over multiple spatial scales, modeling an in depth and more realistic description of the underlying physics (Rahman, Joardder, Khan, Nghia, \& Karim, 2018). Recently, researchers have shown their immense interest in multiscale food drying modeling and provided some general background into the topic through comprehensive reviews (Ho et al., 2013; Rahman, Joardder, Khan, et al., 2018; Welsh et al., 2018). Additionally, some researchers have directly attempted to develop multiscale models for food material (Aregawi, Abera, Fanta, Verboven, \& Nicolai, 2014; Ho et al., 2011). However, their attempts did not consider actual drying conditions as they considered natural dehydration and were developed for other applications such as postharvest storage or for some arbitrary moisture removal without conjugal heat and mass transfer (Wijerathne et al., 2019). To overcome this significant research gap, Welsh et al. (2021) developed a basic multiscale food drying model utilizing knowledge of the microstructural evolution. The work investigated convective drying apple tissue at three different temperatures $\left(45,60\right.$ and $\left.70{ }^{\circ} \mathrm{C}\right)$ and predicted the experimental data well for drying at low/medium temperatures. However, the model utilized unique spatial and temporal averaged microscale domains where a comprehensive experimental knowledge of the microstructural evolution is required to achieve the averages. This necessity significantly increased the experimental cost of the approach. Moreover, to obtain this type of experimental 
validation data requires very sophisticated experimental facilities such as nuclear magnetic resonance (NMR), or X-ray microcomputed tomography which is not always possible or feasible. Moreover, Welsh et al. (2021) model was developed based on the conditiondependent properties, which limits its widespread applicability. The limitations of the microstructural evaluation via experimental facilities and the condition dependency of the model must be minimized. This can be achieved through the development of a theoretical method to estimate the comprehensive cellular properties of the material.

Within published literature, experimental property data is sparse and often unreliable as they vary by 3-5 orders of magnitude for the same material (Dadmohammadi \& Datta, 2019; Saravacos \& Maroulis, 2001). One key property of interest in drying of food material is diffusivity. Effective diffusivity is heavily influenced by its moisture content and temperature distribution and therefore numerous models have been constructed to accurately predict the moisture diffusivity of various food materials during drying (Dadmohammadi \& Datta, 2019). Commonly, all mass transport mechanisms are lumped and Fickian diffusion is assumed. The effective diffusivity is then solved through curve fitting techniques to obtain a constant moisture diffusivity. The resulting property is often unable to consider any variations in material, experimental set up and/or psychrometric drying conditions (Dadmohammadi \& Datta, 2019). To enhance the predictive capabilities of the moisture diffusivity, the Arrhenius framework is applied. This allows the property to be suitable for drying at different temperatures, however, the resulting diffusion coefficient is still condition-dependent and is only suitable for that particular material (i.e. carrot or apple) within that drier configuration.

Researchers have attempted to overcome this issue by developing new approaches, such as the modified Arrhenius approach (Lentzou, Boudouvis, Karathanos, \& Xanthopoulos, 2019) which considers the diffusivity in terms of the materials moisture/deformation. Additionally, Dadmohammadi and Datta (2019) developed a new mechanistic diffusivity function which was 
constructed around porous media modeling and requires unique phase dependent diffusivities for each material. However, these approaches require extensive experimental investigations and therefore generate a dramatic demand in physical and mechanical characterization of each product being dried (Perré, 2007). Additionally, most studies in literature have investigated bulk level moisture and/or temperature dependent diffusivities (Joardder, Karim, Kumar, \& Brown, 2014; Khan, Kumar, Joardder, \& Karim, 2017), neglecting the cell level water transport phenomena (such as cell rupture). Therefore, further investigation into cellular properties and their temporal variations are required for multiscale modeling to be widely adopted for food drying.

Cellular diffusivity properties can be either experimentally investigated or approximated utilizing an inverse problem (optimization). Sibgatullin et al. (2007) investigated the diffusion and relaxation behavior of water in fresh apple parenchyma cells using NMR spectroscopy. Their approach distinguished two components, a slow relaxing component (assigned to the vacuole) for the restrictive diffusion and a fast component (other cell components) for the unrestricted diffusion component. However, this investigation was conducted for fresh apple tissue not food material during drying. Food drying models require temperature and/or moisture dependent properties to describe the complex simultaneous heat and mass transport which occurs. In order to apply Sibgatullin et al. (2007) approach to food drying the technique would need to be repeated in regular intervals in triplicate throughout the drying process. Recently, Dadmohammadi, Kantzas, Yu, and Datta (2020) estimated the permeability and porosity of potato cells using NMR from raw to processed states. The work uncovered permeability coefficients at varying temperatures which can be used to calculate the capillary diffusion in potato tissue. However, investigating these properties experimentally can become time consuming and costly (Khan, Nagy, \& Karim, 2018). 
The alternative approach is to conduct an inverse analysis computationally. If the phase morphology is correctly represented at a cell level, a complete scaling approach can be performed. However, instead of using the multiscale approach to predict macroscopic properties, an inverse analysis can be conducted allowing the local (microscale) properties to be deduced from the macroscopic measurements (Perré, Almeida, Ayouz, \& Frank, 2016). This approach has already been applied to the application of timber drying. Perré et al. (2016) presented a comprehensive strategy to predict different wood properties from anatomical images, particularly focusing on several meshless methods. A key step within the strategy was the representation of the structure which accounted for the local anisotropy and heterogeneity of the cell walls for the material. Inverse problems have also been utilized on macroscale theoretical models. Weres and Olek (2005) developed a finite element analysis strategy for inverse problems. The proposed algorithm was investigated and validated for two types of timber to identify the thermal conductivity, convective heat transfer coefficient, diffusion coefficient, equilibrium moisture content and convective mass transfer coefficient. Lentzou et al. (2019) used an inverse problem in a food drying model. The investigation estimated the effective macroscale diffusivity and mass transfer coefficient in a moving boundary model for fruit isothermal drying and shrinkage. However, an inverse study has not been applied in the context of multiscale food drying modeling to uncover the temporal cellular properties.

To address this important research gap, this work aims to conducts an inverse analysis for deducing the diffusivity of intracellular water while investigating the temporal water heterogeneity of apple tissue during drying. Utilizing an inverse study to develop cellular properties has the ability to efficiently determine a material's properties without the complexity and cost of measuring these properties experimentally. The approach will apply multiscale modeling, specifically homogenization, for convective drying at $60^{\circ} \mathrm{C}$. A temporal heterogeneity investigation will be performed to compare the real cellular water morphology 
and suitable assumptions which can represent the materials evolution. Finally, the most robust approach uncovered within the heterogeneity investigation will be utilized to construct the property for ICW diffusivity.

\section{Materials and methods}

The cellular structure representation is presented first, followed by the multiscale model and solution procedure.

\subsubsection{Cellular structure representation}

The cellular structure of apple consists of a few key components: protoplast (composed of vacuole, tonoplast membrane and cytoplasm), the cell membrane, cell wall and intercellular spaces (Prawiranto et al., 2018). During drying apple tissue deforms and changes due to the various transport mechanisms which occur separately but coexist (Lentzou et al., 2019). Additionally, different cellular deformation can occur when drying at different temperatures (Khan, Farrell, Nagy, \& Karim, 2018; Mahiuddin, Khan, Duc Pham, \& Karim, 2018; Mahiuddin, Khan, Kumar, Rahman, \& Karim, 2018). For this investigation, three distinct stages of cellular deformation will be referred to, cell intact, cell rupturing and ultimate cell rupture. For convective drying, the drying air temperature generally dictates what cellular deformation occurs. For example, when convective drying at temperatures below $50{ }^{\circ} \mathrm{C}$, cells generally remain intact and the composition of cellular water (water within different cellular environments) remains fairly consistent throughout the entire drying period (Khan, Farrell, et

al., 2018). When convective drying at temperatures above $50{ }^{\circ} \mathrm{C}$, cell rupturing occurs, drastically changing the amount of water within different cellular environments (Khan, Farrell, et al., 2018), causing all three stages of cellular deformation to occur. Khan, Farrell, et al. (2018) investigated this phenomenon with NMR and X-ray tomography demonstrating when cells collapse, water rushes out of the cells, moving from the intracellular spaces to intercellular 
spaces and thus becomes free water $(\mathrm{FW})]$. This is visually represented in Figure 1 (c). Once the water becomes free water it can be easily transport therefore changing the transport properties of the material.

This current work investigates convective drying granny smith apples at $60{ }^{\circ} \mathrm{C}$, therefore all three stages of cellular deformation occur, and the cellular water heterogeneity dynamically changes during drying. This makes it ideal to construct a versatile property, however adding complexities to accurately representing the heterogeneity. With this in mind, the microscale domain considered two subdomains, ICW denoted as $\omega_{I C W}$ and FW denoted as $\omega_{F W}$ (Khan \& Karim, 2017), demonstrated in Figure 1. This groups the effects of the protoplast, cell membrane and cell wall within the ICW domain. Additionally, the intercellular spaces were grouped and represented as a circle located within the center of the microscale, Figure 1 (b). This requires minimal microstructural knowledge but forces the effective diffusivity to be isotropic. These microscale domain approximations are constructed from ICW/FW ratios published in Khan, Farrell, et al. (2018) which were measured using NMR, details outlined in section 2.2.6. Anisotropic diffusivity is outside the scope of the current work, however, it can be introduced into this model but ungrouping the intercellular spaces, considering the real cellular structure of the material or considering an off-centered circle. It should be noted, this would significantly increase the cost of the model.

[Figure 1 can be placed here]

\subsection{Multiscale model}

The macroscale transport model used an axisymmetric coordinate system and assumed the following: (1) internal convective flow and heat generation is neglected, (2) drying air 
properties are constant at $60^{\circ} \mathrm{C}$, (3) axisymmetric heating occurs, (4) moisture is only evaporated from the surface and (5) thermal equilibrium exists between all phases. Although food materials are multiphase in nature, contribution gas transport is insignificant in drying. The addition of gas transport in a physics-based model increases its computational cost and does not provide significant benefits for predicting the drying kinetics, particularly in convective drying at $60{ }^{\circ} \mathrm{C}$. Therefore, in this research, it was assumed that the impact of gas transport can be neglected and hence was not included in the model. To achieve the multiscale model, homogenization was applied. Homogenization allows a heterogeneous material to be approximated as a homogeneous medium, replacing a spatially varying property with an effective or equivalent counterpart, visually represented in Figure 1 (a). Homogenization introduces a second scale into the computational model, a microscale, representing the heterogeneous structure of the material, Figure 1 (b) to (d). Homogenization is focused around a limit, where as the scale parameter (the ratio between the length of each scale, $L / \ell$ ) tends to zero, the heterogeneities vanish, leading to a homogeneous material (Pavliotis \& Stuart, 2008). To achieve this goal, an arrangement of periodic microscales can be introduced within the macroscale domain, Figure 1 (a). When assuming a periodic domain, the effective diffusivity can be derived utilising the standard method of homogenization by asymptotic expansion. This routine derivation is well documented in literature (Auriault, Boutin, \& Geindreau, 2010; Carr \& Turner, 2014). Therefore, the microscale mass transport equation is,

$$
\frac{\partial c}{\partial t}+\frac{\partial}{\partial x}\left(-D \frac{\partial c}{\partial x}\right)+\frac{\partial}{\partial y}\left(-D \frac{\partial c}{\partial y}\right)=0
$$

where $c$ is the microscale concentration $\left(\mathrm{mol} \mathrm{m}^{-3}\right)$ and $D$ is the cellular diffusivity $\left(\mathrm{m}^{2} \mathrm{~s}^{-1}\right)$ equaling $D_{I C W}$ if $x, y \epsilon \omega_{I C W}$ and $D_{F W}$ if $x, y \epsilon \omega_{F W}$. The microscale is coupled to the macroscale mass conservation (Golestani, Raisi, \& Aroujalian, 2013), 


$$
\frac{\partial C}{\partial t}+\frac{1}{r} \frac{\partial}{\partial r}\left[-D_{e f f} r \frac{\partial C}{\partial r}\right]+\frac{\partial}{\partial z}\left[-D_{e f f} \frac{\partial C}{\partial z}\right]=0
$$

where $C$ is the macroscale instantaneous moisture concentration $\left(\mathrm{mol} \mathrm{m}^{-3}\right), t$ is the time (s) and $D_{\text {eff }}$ is the effective moisture diffusivity $\left(\mathrm{m}^{2} \mathrm{~s}^{-1}\right)$. In drying food material, the Soret effect (mass flux due to a temperature gradient) is considered to be small (Datta, 2007; Itaya, Kobayashi, \& Hayakawa, 1995) and therefore was not considered. Also, property data on the Soret effect is generally unavailable. As multiscale modeling advances in the field, these effects can be investigated in depth in the future. The 2D homogenized effective diffusivity is given by,

$$
D_{e f f}=\left[\begin{array}{cc}
\frac{1}{\omega} \int_{\omega} D(x, y)\left(\frac{\partial u_{1}}{\partial x}+1\right) d \omega & \frac{1}{\omega} \int_{\omega} D(x, y) \frac{\partial u_{2}}{\partial x} d \omega \\
\frac{1}{\omega} \int_{\omega} D(x, y) \frac{\partial u_{1}}{\partial y} d \omega & \frac{1}{\omega} \int_{\omega} D(x, y)\left(\frac{\partial u_{2}}{\partial y}+1\right) d \omega
\end{array}\right]
$$

and $\omega$ is the area of the microscale domain, $u_{1}$ and $u_{2}$ are the corrective factors and the solution of the periodic cell problem:

$$
\nabla \cdot\left(D \nabla\left(u_{j}+\mathbf{e}_{\mathbf{j}}\right)=0 \quad j=1,2,\right.
$$

where,

$$
\begin{gathered}
\mathbf{e}_{1}=\left[\begin{array}{l}
1 \\
0
\end{array}\right], \quad \mathbf{e}_{2}=\left[\begin{array}{l}
0 \\
1
\end{array}\right], \\
u_{j} \text { is } \omega \text {-periodic, } \\
\frac{1}{\omega} \int_{A} u_{j} d \omega=0 .
\end{gathered}
$$

The solution of $u_{j}$ is unique only up to an additive constant, Equation (4) (Auriault et al., 2010). Therefore, requiring a zero mean constraint to achieve a single unique solution, 
Equation (7). However, the effective homogenized diffusivity only requires the gradient of $u_{j}$, therefore any of these unique solutions are suitable (Carr \& Turner, 2014).

The macroscale energy balance solves for the instantaneous temperature $T(\mathrm{~K})$ based on Fourier's law of heat transfer, given by (Golestani et al., 2013),

$$
\rho c_{p} \frac{\partial T}{\partial t}+\frac{1}{r} \frac{\partial}{\partial r}\left[-k r \frac{\partial T}{\partial r}\right]+\frac{\partial}{\partial z}\left[-k \frac{\partial T}{\partial z}\right]=0
$$

where $\rho$ is the density of apple tissue $\left(\mathrm{kg} \mathrm{m}^{-3}\right), c_{p}$ is the specific heat of apple tissue $\left(\mathrm{J} \mathrm{kg}^{-1} \mathrm{~K}^{-}\right.$ $\left.{ }^{1}\right)$ and $k$ is the thermal conductivity of apple tissue $\left(\mathrm{W} \mathrm{m}^{-1} \mathrm{~K}^{-1}\right)$.

\subsubsection{Boundary conditions}

The mass flux at the exterior boundaries is given by,

$$
\mathbf{n} \cdot\left[-D_{e f f} \nabla C\right]=h_{m} \frac{\left(p_{v e q}-p_{v \text { air }}\right)}{R T}
$$

where $h_{m}$ is the mass transfer coefficient $\left(\mathrm{m} \mathrm{s}^{-1}\right), \mathbf{n}$ is the unit vector normal to the boundary, $p_{v}$ $e q$ is the equilibrium vapor pressure $(\mathrm{Pa}), p_{v \text { air }}$ is the vapor air pressure of ambient air $(\mathrm{Pa})$ and $R$ is the universal gas constant $\left(\mathrm{J} \mathrm{mol}^{-1} \mathrm{~K}^{-1}\right)$. The sorption isotherm of apple tissue was used to derive the equilibrium vapor pressure, $p_{v}$ eq $(\mathrm{Pa})$, given as (Ratti, Crapiste, $\&$ Rotstein, 1989),

$$
p_{v e q}=p_{v s a t}(T) \exp \left(-0.182 M_{d b}^{-0.696}+0.232 e^{-43.949 M_{d b}} M_{d b}^{0.0411} \ln \left[p_{v s a t}(T)\right]\right)
$$

where $p_{v s a t}$ is the saturated vapor pressure of water $(\mathrm{Pa})$ and $M_{d b}$ is the moisture content $\left(\mathrm{kg} \mathrm{kg}^{-}\right.$

${ }^{1}$ dry basis). The saturated vapor pressure is (Vega-Mercado, Marcela Góngora-Nieto, \& Barbosa-Cánovas, 2001),

$$
p_{v \text { sat }}=\exp \left[\begin{array}{l}
-\frac{5800.2206}{T}+1.3915-0.0486 T+ \\
0.4176 \times 10^{-4} T^{2}-0.1445 \times 10^{-7} T^{3}+6.546 \ln (T)
\end{array}\right]
$$


Heat lost due to evaporation and convective heat transfer were incorporated within the heat transfer boundary condition, defined as,

$$
\mathbf{n} \cdot[-k \nabla T]=h_{T}\left(T-T_{a i r}\right)-h_{m} \frac{\left(p_{v e q}-p_{\text {vair }}\right)}{R T} h_{f g} M_{w}
$$

where $h_{T}$ is the heat transfer coefficient $\left(\mathrm{W} \mathrm{m}^{-2} \mathrm{~K}^{-1}\right), T_{\text {air }}$ is the drying air temperature $(\mathrm{K}), M_{w}$ molar mass of water $\left(\mathrm{kg} \mathrm{mol}^{-1}\right)$ and $h_{f g}$ is the latent heat of evaporation $\left(\mathrm{J} \mathrm{kg}^{-1}\right)$. Finally, by symmetry the remaining boundary conditions is,

$$
\begin{gathered}
\mathbf{n} \cdot\left[-D_{e f f} \nabla C\right]=0 \\
\mathbf{n} \cdot[-k \nabla T]=0
\end{gathered}
$$

\subsubsection{Macroscale diffusivity}

The macroscale diffusivity is calculated by one of two techniques, technique 1 through an Arrhenius relationship $\left(D_{1, e f f}\right)$ and technique 2 considering an average $\left(D_{2, e f f}\right)$,

$$
\begin{gathered}
D_{1, e f f}=D_{0} e^{-\frac{E_{a}}{R T}}, \\
D_{2, e f f}=\overline{D_{e f f}}
\end{gathered}
$$

where $D_{o}$ is an integration constant $\left(\mathrm{m}^{2} \mathrm{~s}^{-1}\right), E_{a}$ is the activation energy $\left(\mathrm{J} \mathrm{mol}^{-1}\right)$ and $\overline{D_{\text {eff }}}$ is the average diffusivity $\left(\mathrm{m}^{2} \mathrm{~s}^{-1}\right) . D_{o}, E_{a}$ and $\overline{D_{e f f}}$ will be uncovered through the optimization outlined in Section 2.2.5. As the model was developed based on single-phase moisture transport, Arrhenius law is applicable and commonly used (Kumar, Millar, \& Karim, 2015).

\subsubsection{Other input parameters}


The input parameters used in the model are calculated from the experimental conditions and presented in Table 1. More details on their calculation can be found in appendix A.

\section{[Table 1 can be placed here]}

\subsubsection{Solution Procedure}

Due to the inverse nature of the investigation, the solution procedure contained various steps to construct the property. The full solution procedure is summarized in Figure 2 and outlined in detail below.

\subsubsection{Solving the macroscale model}

The first major step in the solution procedure was to solve the macroscale drying model (denoted in the green subsection in Figure 2). The drying model solves for the heat and mass transport, while calculating the optimal effective diffusivity for the heterogeneity investigation. The effective macroscale diffusivity $\left(D_{\text {eff }}\right)$ is unknown and predicted by minimizing the error between the experimental and predicted moisture content curves over the entire drying period. To implement this, a Levenberg-Marquardt optimization algorithm coupled with the finite element method was applied. The objective function is,

$$
O F\left(D_{e f f}\right)=\int\left[\bar{M}_{d b, \exp }(t)-\bar{M}_{d b, \text { num }}\left(t, D_{i, e f f}\right)\right]^{2} d t
$$

where $\bar{M}_{d b \text {,exp }}$ is the average experimental moisture content (dry bases) and $\bar{M}_{d b, n u m}$ is the average predicted moisture content (dry bases) from the model. The Levenberg-Marquardt algorithm was used for it higher convergence rate in least-square-type problems (Lentzou et al., 2019). The optimization and macroscale heat and mass transport model was solved in COMSOL Multiphysics 5.3a. 


\subsubsection{Temporal heterogeneity investigation}

Once the optimal effective diffusivity is uncovered the temporal heterogeneity investigation can be conducted (denoted in the orange subsection Figure 2). The investigation consists of using the uncovered optimal diffusivity to inversely calculate the diffusivity of ICW, with respect to time, by varying the microscale domains according to the ICW/FW ratio associated with each approach. The investigation considered four approaches: a base case and three approaches to approximate the material's dynamic heterogeneity.

\section{Base case}

The base case for the heterogeneity investigation utilizes published microscale experimental data to consider the ICW/FW ratio in apple tissue drying at $60{ }^{\circ} \mathrm{C}$. This ratio is then used to construct the microscale domain required for the homogenization, allowing a representation of the real cellular water breakdown to be considered. Examples of these microscale domains can be seen in Figure 1 (b) to (d). The specific work which is utilized is Khan, Farrell, et al. (2018). Khan, Farrell, et al. (2018) used NMR to investigate the cellular transport phenomena of apple tissue during convective drying. Their results tracked the ICW and FW breakdown with respect to time. Also, the work demonstrates that ICW migrates from intracellular spaces to intercellular spaces by cell walls progressively rupturing while drying at higher temperatures. Their results are further validated with X-ray tomography images.

Khan, Farrell, et al. (2018) findings are summarized in Figure 3, with examples of the microscale domains constructed from the ratio. It should be noted, within the data there are many fluctuations in the proportions of ICW and FW throughout the drying period. According to the arguments of Khan, Farrell, et al. (2018), these fluctuations are mainly caused by cells collapsing at different stages of drying. The peaks in the ICW content curve indicate the points 
where the cell membranes collapse. Within Figure 3, the total amount of water $(\mathrm{ICW}+\mathrm{FW})$ is considered $100 \%$ at each point of the drying process.

\section{[Figure 3 can be placed here]}

\section{Approaches to approximate the temporal heterogeneity}

The other approaches in the heterogeneity investigation utilize common assumptions to approximate the temporal heterogeneity. These assumptions are important to investigate as considering the real microscale experimental data will not always be possible/feasible due to its cost. Three approaches, each corresponding to an assumption, were investigated to approximate the temporal heterogeneity, approach 2: the average cellular structure, approach 3: ICW content linearly decreases with time and approach 4: diffusivity by stages. All approaches and their associated ICW/FW ratio in relation to time are summarized in Figure 3.

Approach 2 considers the average cellular water ratio with respect to time. This creates a single microscale domain and a constant diffusivity coefficient for the entire drying period. Considering constant diffusivity is very common in literature (Rahman, Joardder, Khan, et al., 2018). Approach 3 assumes the temporal heterogeneity caused by the cell rupturing can be approximated by the ICW content linearly decreasing as drying occurs. This is a basic assumption and aligns with previously published finding (Halder, Datta, \& Spanswick, 2011). Approach 4 introduces a new concept and considers diffusivity in three stages. Each stage corresponds to different cellular deformation stage; stage 1: cells intact, stage 2: cell rupturing occurs and stage 3: ultimate cell rupturing. This approach assumes cell rupturing during stage 2 significantly influences the results and is a key interest of the model. Each stage is defined by the magnitude and fluctuations of ICW in the base case. Stage 1, when the cells are intact, occurs first and is when the ICW content experiences minimal deviation from its initial 
percentage. Stage 2, when cell rupturing occurs, exists in the middle stages of drying when the majority of fluctuations in ICW occur. Stage 3, ultimate cell rupturing, occurs in the latter stages of drying when the percentage of ICW drops off significantly. The stages are represented in Figure 3. Each approach will be investigated and evaluated on their ability to represent the base case, relative experimental cost and applicability to represent ICW diffusivity $\left(D_{I C W}\right)$ as a function. The homogenization and inverse calculation of $D_{I C W}$ was solved using MATLAB 2018a coupled with Gmsh (Geuzaine \& Remacle, 2009) to construct the microscale domains.

\subsection{Property development for the diffusivity of intracellular water}

Once the ideal approach is uncovered the relationship development for diffusivity of ICW $\left(D_{I C W}\right)$ can be conducted (denoted in yellow subsection Figure 2). The property development was considered in terms of two variables, sample temperature $\left(T_{s}\right)$ and ICW content $\left(W C_{I C W}\right)$. Multiple regression with a logarithmic transformation was utilized and solved in MATLAB. After a brief investigation to determine the nature of the data, the initial function for $D_{I C W}$ was assumed as,

$$
D_{I C W}=\exp \left(\beta_{o}+\beta_{1} T_{s}+\beta_{2} W C_{I C W}+\beta_{3} T_{s}^{2}+\beta_{4} W C_{I C W}^{2}\right)
$$

\section{Results:}

The results consist of three main parts, each corresponding to a subsection in the solution procedure: the inverse analysis of the food drying model, the temporal heterogeneity investigation and the estimation of ICW diffusivity. The predicted results were compared to Khan, Farrell, et al. (2018) experimental data to validate the model. Within Khan, Farrell, et al. (2018) the apple samples were dried up to 430 min to reach the products' final equivalent moisture content, around $10-15 \%$ wet basis, for proper preservation. 


\subsection{Inverse analysis on the macroscale effective diffusivity}

The results of the optimization investigation are presented in Figure 4 and Figure 5. The investigation considered two optimal scenarios: assuming an Arrhenius approach to diffusivity [ Equation (15)] and assuming an average effective diffusivity $\left(\overline{D_{\text {eff }}}\right)$ is sufficient [ Equation (16)]. Assuming an Arrhenius approach to diffusivity assumes temperature is the dominant influencer on diffusivity. This resulted in a $D_{o}$ of $8.77 \times 10^{-7} \mathrm{~m}^{2} \mathrm{~s}^{-1}$ and $E_{a}$ of 20.871 $\mathrm{kJ} \mathrm{mol}^{-1}$. This approach predicted moisture transport accurately with a low mean relative error (MRE) of 5.96\% (Figure 4). The average temperature profile also described the experimental data well with a MRE of $1.97 \%$. The value for the integration constant $\left(E_{a}\right)$ agrees with the existing literature falling within the expected range of $12.7-110 \mathrm{~kJ} \mathrm{~mol}^{-1}$ for various food and agricultural material (Zogzas, Maroulis, \& Marinos-Kouris, 1996). In particular, $E_{a}$ for apple has been reported at $24.51 \mathrm{~kJ} \mathrm{~mol}^{-1}$ for drying at $40-60^{\circ} \mathrm{C}$ (Wang, Sun, et al., 2007) and 29.65 $\mathrm{kJ} \mathrm{mol}^{-1}$ for drying at $50-80^{\circ} \mathrm{C}$ (Kara \& Doymaz, 2015).

The alternative approach (optimal scenario 2) found an optimal average effective diffusivity $\left(D_{e f f}\right)$ of $3.30 \times 10^{-10} \mathrm{~m}^{2} \mathrm{~s}^{-1}$ with MREs of $5 \%$ and $1.77 \%$ for the average moisture and temperature profiles respectively. This effective diffusivity fell within the expected diffusivity range for most food material, $10^{-9}-10^{-11} \mathrm{~m}^{2} \mathrm{~s}^{-1}$ (Panagiotou, Krokida, Maroulis, \& Saravacos, 2004; Saravacos \& Maroulis, 2001). Additionally, as expected the calculated diffusivities were less than the self-diffusion of water at $60{ }^{\circ} \mathrm{C}\left(4.748 \times 10^{-9} \mathrm{~m}^{2} \mathrm{~s}^{-1}\right)$ (Lentzou et al., 2019). The effective diffusivity can also be compared to $0.713 \times 10^{-11}-7.66 \times 10^{-10} \mathrm{~m}^{2} \mathrm{~s}^{-1}$ for

Red Delicious apples at a temperature range of $35-55^{\circ} \mathrm{C}$ (Beigi, 2016).

[Figure 4 can be placed here]

[Figure 5 can be placed here] 


\subsection{Temporal heterogeneity investigation}

Investigating the temporal heterogeneity utilizing an inverse study can be complex. Due to the nature of the approach, the diffusivity of ICW is inversely calculated. This means all approaches essentially achieve the same macroscale diffusivity result. This can make it hard to evaluate the performance of each approach. However, each approach creates unique relationships for the diffusivity of ICW, and not all these relationships can be easily described by functions for future models. The end goal of applying multiscale modeling is to move towards a more mechanistic modeling approach. This cannot be achieved without suitable property relationships at a microscale. Therefore, each approach is evaluated on their ability to represent the real cellular water breakdown (base case), relative experimental cost and applicability to represent ICW diffusivity $\left(D_{I C W}\right)$ as a function.

The results of the temporal heterogeneity investigation can be seen within Figure 6 to Figure 9. Approach 1 considered previously published experimental results to create a base case of achieving an optimal Arrhenius relationship. The approach assumed optimal scenario 1 was ideal and the results can be seen in Figure 6. Within the experimental data, the FW content fluctuates, and when considering two subdomains at a microscale this trend is reflected in the diffusivity of ICW. The diffusivity initially increases, however, once cell rupturing occurs, the diffusivity oscillates. Towards the end, ultimate cell rupturing occurs causing the diffusivity of ICW to drastically drop to achieve the optimal Arrhenius trend. It should be noted, it is likely there is a few mechanisms occurring at the latter stage of drying contributing to the low diffusivity of the ICW subdomain. The ICW subdomain encompasses the protoplast, cell membrane and cell wall which are known to deform/change due to the drying process. Joardder, Brown, Kumar, and Karim (2015) demonstrated that the cell wall thickness halved during convective drying of Granny Smith apples. Prawiranto et al. (2018) modeled the 
dehydration of cellular food tissue (at an air temperature of $25^{\circ} \mathrm{C}$ ). The work theorized and demonstrated that the dried material forms an additional barrier restricting the moisture within the sample in the later stages of dehydration. The presence of cell rupturing likely causes the additional restricting barrier to have a smaller effect on the diffusivity in the later stages of drying. However, it could still be contributing to the drastic drop off.

\section{[Figure 6 can be placed here]}

Approach 2 considered the average ICW content from the base case to construct the microscale domain. The approach considered optimal scenario 2 and the results can be seen in Figure 7. Approach 2 resulted in a single microscale domain and a single $D_{I C W}$ for the duration of drying. Considering the average diffusivity rather than the temperature dependent approach (Arrhenius relationship) resulted in slightly lower MREs, however the approach required comprehensive knowledge of the microstructural evolution of the sample (comprehensive experimental data). Specifically, approach 2 considers the average ICW content over the entire drying period to construct its microscale domain. Recording the ratio of cellular water content is not trivial and requires an NMR or similar approach (Khan et al., 2016). Approach 2 resulted in an average ICW diffusivity of $1.5 \times 10^{-10} \mathrm{~m}^{2} \mathrm{~s}^{-1}$. Most literature on the diffusivity of food material during drying has only investigated the tissue level (macroscale) (Welsh et al., 2018). This adds complexity to comparing the average ICW diffusivity uncovered. Research has been published on the ICW diffusivity of fresh Granny Smith apples (high moisture content) with a value of $3.8 \times 10^{-10} \mathrm{~m}^{2} \mathrm{~s}^{-1}$ (Sibgatullin et al., 2007). Convective drying significantly effects the

material's diffusion process due to the continuous moisture loss and cell ruptures. Additionally, it is known that the effective diffusivity decreases with the decrease in the moisture content in the sample (Dadmohammadi \& Datta, 2019).

[Figure 7 can be placed here] 
Approach 3 assumes that the fluctuating experimental results can be approximated through assuming a linear decrease in the ICW content at the microscale. Assuming a linear decrease in ICW content (representing cellular deformation/rupturing) is consistent with Halder et al. (2011). The results for this approach can be seen in Figure 8. The diffusivity initially increases similar to base case. After the initial increase, the ICW diffusivity progressively decreases to achieve the Arrhenius relationship. The approach resulted in an ICW diffusivity range of $1.92 \times 10^{-10}$ to $1.12 \times 10^{-11} \mathrm{~m}^{2} \mathrm{~s}^{-1}$.

\section{[Figure 8 can be placed here]}

Approach 4 considers diffusivity in individual stages. The stages are defined on the cellular deformation which occurs throughout the drying process. For convective drying at 60 ${ }^{\circ} \mathrm{C}$, three stages were considered: stage 1 cell membrane are intact, stage 2 progressive cell rupturing occurs and stage 3 ultimate cell rupturing. This approach results in separate diffusivities and microscale domains for each stage, Figure 9. The microscale domains were constructed through utilizing the same experiment data as the base approach to create averages for each stage.

\section{[Figure 9 can be placed here]}

\subsection{Comparison of temporal heterogeneity approaches}

Approach 2 (average), approach 3 (linear decrease) and approach 4 (diffusivity by stages) all approximate the cellular deformation of approach 1 (base case) through different assumptions. Considering the average or diffusivity by stages requires comprehensive knowledge of the microstructural evolution which generally results in high experimental cost.

These approaches do describe the temporal heterogeneity, however multiscale models excel in optimization scenarios where modeling is utilized to calculate the optimal drying conditions and dryer design taking advantage of generalized properties. As comprehensive knowledge of 
the microstructure evolution is required, considering the average or diffusivity by stages would limit the model's advantages in these situations, restricting the applications of any property constructed. Additionally, approach 4 (diffusivity by stages) is an interesting concept but shows no significant advantage in this application. The approach could show potential at higher drying temperatures where significant changes to a materials microstructure occur within a particular stage, i.e. case hardening.

Approach 3 (linear decrease) is interesting. The approach requires some microstructural knowledge (i.e. the initial and final ICW content) however significantly less microstructural knowledge compared to the other approaches. Additionally, literature already exists for the initial ICW content for a variety of fruits and vegetables, which minimizes the experimental cost (Halder et al., 2011; Khan et al., 2016). Approach 3 also demonstrated the most practicality. The approach was able the capture the initial increase in ICW diffusivity which occurred within the base case, before progressively decreasing to achieve the Arrhenius relationship. Therefore, approach 3 (linear decrease) was selected for the property development.

\subsection{Diffusivity estimation for ICW}

Approach 3 (linear decrease) was utilized for the ICW diffusivity relationship development. The property was developed in terms of sample temperature $\left(T_{S}\right)$ and intracellular water content $\left(W C_{I C W}\right)$. The finalized function was,

$D_{I C W}=\exp \left[-110.32+0.55536 T_{s}+0.095148 W C_{I C W}-0.00090738 T_{s}^{2}-0.0007235 W C_{I C W}^{2}\right]$ 
A visualization of the ICW diffusivity function can be found in Figure 10. Within this contour plot, the ICW diffusivity for any given sample temperature and ICW content can be seen within the given range. All coefficients have P-values under 0.05 and thus were considered significant. The function has a $\mathrm{R}^{2}$ of 0.999 , though, it should be noted the property is developed off the assumption (linear decrease) with a small data set. Some interesting observations can be made by investigating and comparing this function to published literature. The ICW content trend for apple tissue has been reported for convective drying at 45,60 and $70^{\circ} \mathrm{C}$ (Khan, Farrell, et al., 2018). The work reported that at low drying temperatures $\left(45^{\circ} \mathrm{C}\right)$ the ICW content remains fairly constant $(88 \%-79 \%)$ whereas at medium to high temperatures (above $50^{\circ} \mathrm{C}$ ) the ICW fluctuates before dropping off in the latter stages of drying. Additionally, other authors have also demonstrated this trend for other food materials (Halder et al., 2011). The current study investigates drying at $60^{\circ} \mathrm{C}$. To further investigate the proposed function, a case study for drying apples at $45^{\circ} \mathrm{C}$ can be considered. When convective drying at $45^{\circ} \mathrm{C}$, it is known minimal fluctuations in the $W C_{I C W}$ occur (78-88\%) in apple tissue (Khan, Farrell, et al., 2018). Additionally, the product will only experience temperatures between $25^{\circ} \mathrm{C}$ (its initial temperature) to $45^{\circ} \mathrm{C}$ (its possible maximum). If these are considered within the developed function, the resulting ICW diffusivity would be between $1.41 \times 10^{-10}$ to $1.8 \times 10^{-10} \mathrm{~m}^{2} \mathrm{~s}^{-1}$. When this potential minimum and maximum of the material's ICW diffusivity is upscaled through homogenization, the effective macroscale diffusivity of the material would be $1.99 \times 10^{-10}$ to $2.569 \times 10^{-10} \mathrm{~m}^{2} \mathrm{~s}^{-1}$, which agrees with published literature (Beigi, 2016; Kara \& Doymaz, 2015).

[Figure 10 can be placed here] 
Though the proposed function [Equation (19)] is constructed for apple, the ICW content $\left(W C_{I C W}\right)$ and its trend are different for each food material during drying. This opens the possibility to apply the function to other food materials. Literature has reported the initial ICW content for various fruits and vegetables i.e. apricot, pear, potato and eggplant (Halder et al., 2011; Khan et al., 2016), however much more work is still required. Therefore, the robustness of the proposed equation and its applicability to other food materials must be investigated in future works with a larger dataset. The proposed function does have the possibility of transitioning towards a generalized diffusivity for food material during drying. Note that the residuals for the proposed function can be found in Appendix A.

\section{Discussion and outlook}

The developed relationship for ICW diffusivity considers two subdomains at the microscale, ICW and FW. This allows the water heterogeneity to be considered while maintaining a reasonable computational cost. The magnitude of the effective diffusivity uncovered within the inverse analysis is on the mid to lower end of the expected range, $10^{-9}$ $10^{-11} \mathrm{~m}^{2} \mathrm{~s}^{-1}$ (Panagiotou et al., 2004; Saravacos \& Maroulis, 2001), for food material. This is important to remember when evaluating the proposed equation for property prediction. The existing macroscale effective diffusivity data within literature should be treated cautiously. Many of the published values are larger than the reported coefficients for self-diffusion and/or diffusion of species in the solvent with no porous structure (Lentzou et al., 2019). Also, many consider an idealized non-deforming geometry, often causing large error between the predictive model and experimental data towards the end of drying (Tzempelikos et al., 2015).

The effective macroscale moisture diffusivity could be $0.1-50 \%$ smaller than free diffusion as the food matrices are porous media (Khaled \& Vafai, 2003). Deformation is an important factor 
to consider (Joardder, Kumar, Brown, \& Karim, 2015). Whether it's to model the physical process (Mayor \& Sereno, 2004) or to incorporate its effects within the appropriate properties. This research incorporated its effects through the inverse study and heterogeneity consideration. Also, alternatively a basic method of incorporating some shrinkage is to consider the average radius within Fick's equation rather than the initial radius.

The developed relationship for ICW diffusivity encompasses the effects of the vacuole, tonoplast membrane, cytoplasm, cell membrane and cell wall. This is because only two subdomains are considered at the microscale. This lumping could have a negative effect on the proposed functions applicability to other food materials. The developed ICW diffusivity function is in terms of temperature and the moisture content of the intracellular sub-domain (ICW moisture). This allows the developed property to be theoretically suitable for a wide range of psychrometric drying conditions. Additionally, as the property was developed through a temporal heterogeneity investigation while drying at $60^{\circ} \mathrm{C}$ cell rupturing was considered, improving the developed property's predictive capabilities when significant cell rupturing occurs. Theoretical models nowadays have become more complex and more physics-based which allows the generalization of properties to become a real possibility in the near future.

\section{Conclusion}

The development of the property relationship for ICW is a step towards a more mechanistic approach to diffusivity. The inverse analysis and temporal heterogeneity investigation allowed the real temporal cellular morphology to be investigated and appropriate assumptions to be compared. The property relationship was developed in terms of two variables, material temperature and intracellular water content. This opens the possibility of using the function for other food materials, however the proposed function is yet to be validated 
for food material other than apple. Additionally, though the ICW diffusivity relationship was constructed from approach 3 (linear decrease), the temporal heterogeneity investigation provides insight into different options available to consider the temporal heterogeneity of the material. The other approaches investigated can be used in different scenarios where they are suitable. For example, the average ICW diffusivity can be used to cut down on computational cost when knowledge of the microstructural evolution is well known and considering diffusivity by stage can be used when the effect of cell rupturing is of key interest. The proposed function for ICW diffusivity will allow future models to consider a more realistic description of the physics during food drying. Additionally, the inverse method developed can be applied to other properties (i.e. thermal conductivity) to further improve the accuracy and predictive capabilities of mathematical models for food drying.

\section{Acknowledgements}

This study was funded by the Department of Education and Training (AUS) through a Research Training Program (Stipend) Domestic (RTP) scholarship.

\section{References}

Aregawi, W. A., Abera, M. K., Fanta, S. W., Verboven, P., \& Nicolai, B. (2014). Prediction of water loss and viscoelastic deformation of apple tissue using a multiscale model. $J$ Phys Condens Matter, 26(46), 464111. https://doi.org/10.1088/0953-8984/26/46/464111

Auriault, J.-L., Boutin, C., \& Geindreau, C. (2010). Homogenization of coupled phenomena in heterogenous media (Vol. 149): John Wiley \& Sons. 
Bahammou, Y., Lamsyehe, H., Kouhila, M., Lamharrar, A., Idlimam, A., \& Abdenouri, N. (2019). Valorization of co-products of sardine waste by physical treatment under natural and forced convection solar drying. Renewable Energy, 142, 110-122. https://doi.org/10.1016/j.renene.2019.04.012

Bahammou, Y., Moussaoui, H., Lamsayeh, H., Tagnamas, Z., Kouhila, M., Ouaabou, R., . . Idlimam, A. (2020). Water sorption isotherms and drying characteristics of rupturewort (Herniaria hirsuta) during a convective solar drying for a better conservation. Solar Energy, 201, 916-926. https://doi.org/10.1016/j.solener.2020.03.071

Beigi, M. (2016). Influence of drying air parameters on mass transfer characteristics of apple slices. Heat and Mass Transfer, 52(10), 2213-2221. https://doi.org/10.1007/s00231$\underline{015-1735-8}$

Białobrzewski, I. (2006). Simulation of changes in the density of an apple slab during drying. International Communications in Heat and Mass Transfer, 33(7), 880-888. https://doi.org/10.1016/j.icheatmasstransfer.2006.02.017

Carr, E. J., \& Turner, I. W. (2014). Two-scale computational modelling of water flow in unsaturated soils containing irregular-shaped inclusions. International Journal for Numerical Methods in Engineering, 98, 157-173. https://doi.org/10.1002/nme.4625

Cengel, Y. (2003). Heat, Transfer Mass: A practical approach: Mc-Graw Hill Education, Columbus, GA, USA.

Cengel, Y. A., \& Boles, M. A. (2002). Thermodynamics: an engineering approach. Sea, 1000, 8862.

Dadmohammadi, Y., \& Datta, A. K. (2019). Prediction of effective moisture diffusivity in plant tissue food materials over extended moisture range. Drying Technology, 1-15. https://doi.org/10.1080/07373937.2019.1690500 
Dadmohammadi, Y., Kantzas, A., Yu, X., \& Datta, A. K. (2020). Estimating permeability and porosity of plant tissues: Evolution from raw to the processed states of potato. Journal of Food Engineering, 277, 109912. https://doi.org/10.1016/j.jfoodeng.2020.109912

Datta, A. K. (2007). Porous media approaches to studying simultaneous heat and mass transfer in food processes. I: Problem formulations. Journal of Food Engineering, 80(1), 80-95. https://doi.org/10.1016/j.jfoodeng.2006.05.013

Geuzaine, C., \& Remacle, J. F. (2009). Gmsh: A 3-D finite element mesh generator with builtin pre-and post-processing facilities. International journal for numerical methods in engineering, 79(11), 1309-1331. https://doi.org/10.1002/nme.2579

Golestani, R., Raisi, A., \& Aroujalian, A. (2013). Mathematical modeling on air drying of apples considering shrinkage and variable diffusion coefficient. Drying Technology, 31, 40-51. https://doi.org/10.1080/07373937.2012.714826

Halder, A., Datta, A. K., \& Spanswick, R. M. (2011). Water transport in cellular tissues during thermal processing. AIChE Journal, 57(9), 2574-2588. https://doi.org/10.1002/aic.12465

Ho, Q. T., Carmeliet, J., Datta, A. K., Defraeye, T., Delele, M. A., Herremans, E., . . Nicolai, B. M. (2013). Multiscale modeling in food engineering. Journal of Food Engineering, 114, 279-291. https://doi.org/10.1016/j.jfoodeng.2012.08.019

Ho, Q. T., Verboven, P., Verlinden, B. E., Herremans, E., Wevers, M., Carmeliet, J., \& Nicolaï, B. M. (2011). A 3-D multiscale model for gas exchange in fruit. Plant Physiol, pp. 110.169391. https://doi.org/10.1104/pp.110.169391

Incropera, F. P., Bergman, T. L., Lavine, A. S., \& Dewitt, D. P. (2011). Fundamentals of heat and mass transfer (Vol. 7th). Hoboken, N.J: John Wiley.

Itaya, Y., Kobayashi, T., \& Hayakawa, K.-I. (1995). Three-dimensional heat and moisture transfer with viscoelastic strain-stress formation in composite food during drying. 
International Journal of Heat and Mass Transfer, 38(7), 1173-1185. https://doi.org/10.1016/0017-9310(94)00245-Q

Joardder, M. U., Brown, R. J., Kumar, C., \& Karim, M. (2015). Effect of cell wall properties on porosity and shrinkage of dried apple. International Journal of Food Properties, 18(10), 2327-2337. https://doi.org/10.1080/10942912.2014.980945

Joardder, M. U., Karim, A., Kumar, C., \& Brown, R. J. (2014). Determination of effective moisture diffusivity of banana using thermogravimetric analysis. Procedia Engineering, 90, 538-543. https://doi.org/10.1016/j.proeng.2014.11.769

Joardder, M. U., Kumar, C., Brown, R. J., \& Karim, M. (2015). A micro-level investigation of the solid displacement method for porosity determination of dried food. Journal of Food Engineering, 166, 156-164. https://doi.org/10.1016/j.jfoodeng.2015.05.034

Kara, C., \& Doymaz, İ. (2015). Effective moisture diffusivity determination and mathematical modelling of drying curves of apple pomace. Heat and Mass transfer, 51(7), 983-989. https://doi.org/10.1007/s00231-014-1470-6

Khaled, A. R. A., \& Vafai, K. (2003). The role of porous media in modeling flow and heat transfer in biological tissues. International Journal of Heat and Mass Transfer, 46(26), 4989-5003. https://doi.org/10.1016/S0017-9310(03)00301-6

Khan, M. I. H., Farrel1, T., Nagy, S. A., \& Karim, M. A. (2018). Fundamental Understanding of Cellular Water Transport Process in Bio-Food Material during Drying. Scientific Reports, 8(1), 15191. https://doi.org/10.1038/s41598-018-33159-7

Khan, M. I. H., Joardder, M. U. H., Kumar, C., \& Karim, M. A. (2018). Multiphase porous media modelling: A novel approach to predicting food processing performance. Critical reviews in food science and nutrition, 1-19. https://doi.org/10.1080/10408398.2016.1197881 
Khan, M. I. H., \& Karim, M. (2017). Cellular water distribution, transport, and its investigation methods for plant-based food material. Food Research International, 99, 1-14. https://doi.org/10.1016/j.foodres.2017.06.037

Khan, M. I. H., Kumar, C., Joardder, M. U. H., \& Karim, M. (2017). Determination of appropriate effective diffusivity for different food materials. Drying Technology, 35(3), 335-346. https://doi.org/10.1080/07373937.2016.1170700

Khan, M. I. H., Nagy, S. A., \& Karim, M. A. (2018). Transport of cellular water during drying: An understanding of cell rupturing mechanism in apple tissue. Food Research International, 105, 772-781. https://doi.org/10.1016/j.foodres.2017.12.010

Khan, M. I. H., Wellard, R. M., Nagy, S. A., Joardder, M. U. H., \& Karim, M. A. (2016). Investigation of bound and free water in plant-based food material using NMR T2 relaxometry. Innovative Food Science \& Emerging Technologies, 38, 252-261. https://doi.org/10.1016/j.ifset.2016.10.015

Khan, M. I. H., Wellard, R. M., Nagy, S. A., Joardder, M. U. H., \& Karim, M. A. (2017). Experimental investigation of bound and free water transport process during drying of hygroscopic food material. International Journal of Thermal Sciences, 117(Supplement C), 266-273. https://doi.org/10.1016/j.ijthermalsci.2017.04.006

Khan, M. Imran H., Welsh, Z., Gu, Y., Karim, M. A., \& Bhandari, B. (2020). Modelling of simultaneous heat and mass transfer considering the spatial distribution of air velocity during intermittent microwave convective drying. International Journal of Heat and Mass Transfer, 153, 119668. https://doi.org/10.1016/j.ijheatmasstransfer.2020.119668

Kumar, C., Joardder, M. U. H., Farrell, T. W., Millar, G. J., \& Karim, M. A. (2016). Mathematical model for intermittent microwave convective drying of food materials. Drying Technology, 34(8), 962-973. https://doi.org/10.1080/07373937.2015.1087408 
Kumar, C., Millar, G. J., \& Karim, M. A. (2015). Effective Diffusivity and Evaporative Cooling in Convective Drying of Food Material. Drying Technology, 33(2), 227-237. https://doi.org/10.1080/07373937.2014.947512

Lentzou, D., Boudouvis, A. G., Karathanos, V. T., \& Xanthopoulos, G. (2019). A moving boundary model for fruit isothermal drying and shrinkage: An optimization method for water diffusivity and peel resistance estimation. Journal of Food Engineering, 263, 299-310. https://doi.org/10.1016/j.jfoodeng.2019.07.010

Mahiuddin, M., Khan, M. I. H., Duc Pham, N., \& Karim, M. A. (2018). Development of fractional viscoelastic model for characterizing viscoelastic properties of food material during drying. Food Bioscience, 23, 45-53. https://doi.org/10.1016/j.fbio.2018.03.002

Mahiuddin, M., Khan, M. I. H., Kumar, C., Rahman, M. M., \& Karim, M. (2018). Shrinkage of food materials during drying: Current status and challenges. Comprehensive Reviews in Food Science and Food Safety, 17(5), 1113-1126. https://doi.org/10.1111/1541$\underline{4337.12375}$

Mavroudis, N. E., Gekas, V., \& Sjöholm, I. (1998). Osmotic dehydration of apples-effects of agitation and raw material characteristics. Journal of Food Engineering, 35(2), 191209. https://doi.org/10.1016/S0260-8774(98)00015-6

Mayor, L., \& Sereno, A. M. (2004). Modelling shrinkage during convective drying of food materials: a review. Journal of Food Engineering, 61(3), 373-386. https://doi.org/10.1016/S0260-8774(03)00144-4

Pace, E. L. (1962). Scientific foundations of vacuum technique (Dushman, Saul). Journal of Chemical Education, 39(8), A606. https://doi.org/10.1021/ed039pA606

Panagiotou, N., Krokida, M., Maroulis, Z., \& Saravacos, G. (2004). Moisture diffusivity: literature data compilation for foodstuffs. International Journal of Food Properties, 7(2), 273-299. https://doi.org/10.1081/JFP-120030038 
Pavliotis, G. A., \& Stuart, A. (2008). Multiscale methods: averaging and homogenization: Springer Science \& Business Media.

Perré, P. (2007). Multiscale aspects of heat and mass transfer during drying. Transport in Porous Media, 66, 59-76. https://doi.org/10.1007/s11242-006-9022-2

Perré, P., Almeida, G., Ayouz, M., \& Frank, X. (2016). New modelling approaches to predict wood properties from its cellular structure: image-based representation and meshless methods. Annals of Forest Science, 73(1), 147-162. https://doi.org/10.1007/s13595$\underline{015-0519-0}$

Pham, D. N., Khan, M. I. H., Joardder, M. U. H., Rahman, M. M., Mahiuddin, M., Abesinghe, A. M. N., \& Karim, M. A. (2019). Quality of plant-based food materials and its prediction during intermittent drying. Crit Rev Food Sci Nutr, 59(8), 1197-1211. https://doi.org/10.1080/10408398.2017.1399103

Pham, N. D., Khan, M., \& Karim, M. (2020). A mathematical model for predicting the transport process and quality changes during intermittent microwave convective drying. Food Chemistry, 126932. https://doi.org/10.1016/j.foodchem.2020.126932

Prawiranto, K., Defraeye, T., Derome, D., Verboven, P., Nicolai, B., \& Carmeliet, J. (2018). New insights into the apple fruit dehydration process at the cellular scale by 3D continuum modeling. Journal of Food Engineering, 239, 52-63. https://doi.org/10.1016/j.jfoodeng.2018.06.023

Rahman, M. M., Gu, Y., \& Karim, M. (2018). Development of realistic food microstructure considering the structural heterogeneity of cells and intercellular space. Food Structure, 15, 9-16. https://doi.org/10.1016/j.foostr.2018.01.002

Rahman, M. M., Joardder, M. U., \& Karim, A. (2018). Non-destructive investigation of cellular level moisture distribution and morphological changes during drying of a plant-based 
food material. Biosystems Engineering, 169, 126-138. https://doi.org/10.1016/j.biosystemseng.2018.02.007

Rahman, M. M., Joardder, M. U. H., Khan, M. I. H., Nghia, D. P., \& Karim, M. A. (2018). Multi-scale model of food drying: Current status and challenges. Critical Reviews in Food Science and Nutrition. https://doi.org/10.1080/10408398.2016.1227299

Ratti, C., Crapiste, G., \& Rotstein, E. (1989). A new water sorption equilibrium expression for solid foods based on thermodynamic considerations. Journal of Food Science, 54(3), 738-742. https://doi.org/10.1111/j.1365-2621.1989.tb04693.x

Saravacos, G. D., \& Maroulis, Z. B. (2001). Transport properties of foods: CRC Press.

Sibgatullin, T., De Jager, P., Vergeldt, F., Gerkema, E., Anisimov, A., \& Van As, H. (2007). Combined analysis of diffusion and relaxation behavior of water in apple parenchyma cells. Biophysics, 52(2), 196-203. https://doi.org/10.1134/S0006350907020091

Tzempelikos, D. A., Mitrakos, D., Vouros, A.P., Bardakas, A. V., Filios, A. E., \& Margaris, D. P. (2015). Numerical modeling of heat and mass transfer during convective drying of cylindrical quince slices. Journal of Food Engineering, 156, 10-21. https://doi.org/10.1016/j.jfoodeng.2015.01.017

Vega-Mercado, H., Marcela Góngora-Nieto, M., \& Barbosa-Cánovas, G. V. (2001). Advances in dehydration of foods. Journal of Food Engineering, 49(4), 271-289. https://doi.org/10.1016/S0260-8774(00)00224-7

Wang, W., Chen, G., \& Mujumdar, A. S. (2007). Physical interpretation of solids drying: An overview on mathematical modeling research. Drying Technology, 25(4), 659-668. https://doi.org/10.1080/07373930701285936

Wang, Z., Sun, J., Liao, X., Chen, F., Zhao, G., Wu, J., \& Hu, X. (2007). Mathematical modeling on hot air drying of thin layer apple pomace. Food Research International, 40(1), 39-46. https://doi.org/10.1016/j.foodres.2006.07.017 
Welsh, Z., Simpson, M. J., Khan, M. I. H., \& Karim, M. (2018). Multiscale Modeling for Food Drying: State of the Art. Comprehensive Reviews in Food Science and Food Safety, 17(5), 1293-1308. https://doi.org/10.1111/1541-4337.12380

Welsh, Z. G., Khan, M. I. H., \& Karim, M. (2021). Multiscale modeling for food drying: A homogenized diffusion approach. Journal of Food Engineering, 292, 110252. https://doi.org/10.1016/j.jfoodeng.2020.110252

Weres, J., \& Olek, W. (2005). Inverse Finite Element Analysis of Technological Processes of Heat and Mass Transport in Agricultural and Forest Products. Drying Technology, 23(8), 1737-1750. https://doi.org/10.1081/DRT-200065191

Whitaker, S. (1977). Simultaneous Heat, Mass, and Momentum Transfer in Porous Media: A Theory of Drying. Advances in Heat Transfer, 13, 119-203. http://dx.doi.org/10.1016/S0065-2717(08)70223-5

Wijerathne, W., Rathnayaka, C., Karunasena, H., Senadeera, W., Sauret, E., Turner, I., \& Gu, Y. (2019). A coarse-grained multiscale model to simulate morphological changes of food-plant tissues undergoing drying. Soft matter, 15, 901-916. https://doi.org/10.1039/C8SM01593G

Zogzas, N. P., Maroulis, Z. B., \& Marinos-Kouris, D. (1996). Moisture Diffusivity Data Compilation in Foodstuffs. Drying Technology, 14(10), 2225-2253. https://doi.org/10.1080/07373939608917205 
Tables:

Table 1. Input parameters

\begin{tabular}{|c|c|c|}
\hline Parameter & Value (unit) & Reference \\
\hline Density of apple, $\rho$ & $837\left(\mathrm{~kg} \mathrm{~m}^{-3}\right)$ & $\begin{array}{l}\text { Mavroudis, Gekas, } \\
\text { and Sjöholm (1998) }\end{array}$ \\
\hline Density of water, $\rho_{w}$ & $995\left(\mathrm{~kg} \mathrm{~m}^{-3}\right)$ & Cengel (2003) \\
\hline Specific heat of apple, $c_{p}$ & $1000\left(1.4+3.22 M_{w b}\right)\left(\mathrm{J} \mathrm{kg}^{-1} \mathrm{~K}^{-1}\right)$ & $\begin{array}{l}\text { (Białobrzewski, } \\
\text { 2006) }\end{array}$ \\
\hline $\begin{array}{l}\text { Thermal conductivity of apple, } \\
k\end{array}$ & $0.0148+0.000493 M_{w b}\left(\mathrm{~W} \mathrm{~m}^{-1} \mathrm{~K}^{-1}\right)$ & (Białobrzewski, \\
\hline Initial moisture content, $M_{0}$ & $6.4\left(\mathrm{~kg} \mathrm{~kg}^{-1}\right.$ dry bases $)$ & This study \\
\hline Initial sample temperature, $T_{0}$ & $296(\mathrm{~K})$ & This study \\
\hline $\begin{array}{l}\text { Equilibrium moisture content, } \\
M_{e}\end{array}$ & $0.2\left(\mathrm{~kg} \mathrm{~kg}^{-1}\right.$ & $\begin{array}{l}\text { Białobrzewski } \\
(2006)\end{array}$ \\
\hline $\begin{array}{l}\text { Initial wet basis moisture } \\
\text { content, } M_{\mathrm{O}_{w b}}\end{array}$ & $0.86\left(\mathrm{~kg} \mathrm{~kg}^{-1}\right.$ wet bases $)$ & This study \\
\hline Latent heat of evaporation, $h_{f g}$ & $2358600\left(\mathrm{~J} \mathrm{~kg}^{-1}\right)$ & Cengel (2003) \\
\hline Universal gas constant, $R$ & $8.314\left(\mathrm{~J} \mathrm{~mol}^{-1} \mathrm{~K}^{-1}\right)$ & $\begin{array}{l}\text { Cengel and Boles } \\
\text { (2002) }\end{array}$ \\
\hline Molar mass of water, $M_{w}$ & $0.018016\left(\mathrm{~kg} \mathrm{~mol}^{-1}\right)$ & $\begin{array}{l}\text { Cengel and Boles } \\
\text { (2002) }\end{array}$ \\
\hline Partial vapor pressure, $p_{v}$ air & $2000(\mathrm{~Pa})$ & This study \\
\hline Heat transfer coefficient, $h_{T}$ & $19.98\left(\mathrm{~W} \mathrm{~m}^{-2} \mathrm{~K}^{-1}\right)$ & This study \\
\hline Mass transfer coefficient, $h_{m}$ & $0.018\left(\mathrm{~m} \mathrm{~s}^{-1}\right)$ & This study \\
\hline Diffusivity of $\mathrm{FW}, D_{F W}$ & $2.26 \times 10^{-5}\left[\frac{T}{273.15}\right]^{1.81}\left(\mathrm{~m}^{2} \mathrm{~s}^{-1}\right)$ & Pace (1962) \\
\hline
\end{tabular}




\section{Figures:}

a)

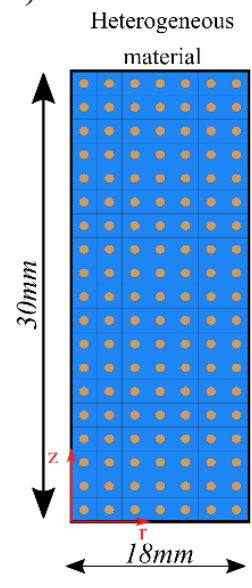

b)

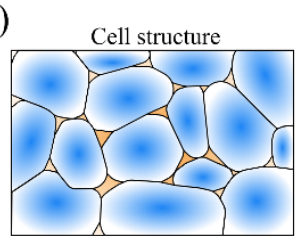

c)

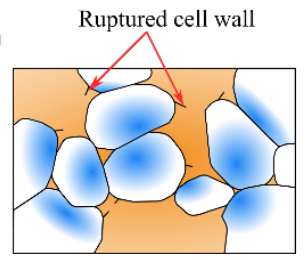

Grouped intracellular water

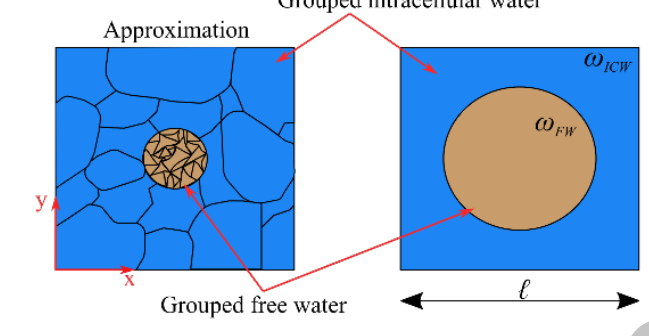

Drying time d)
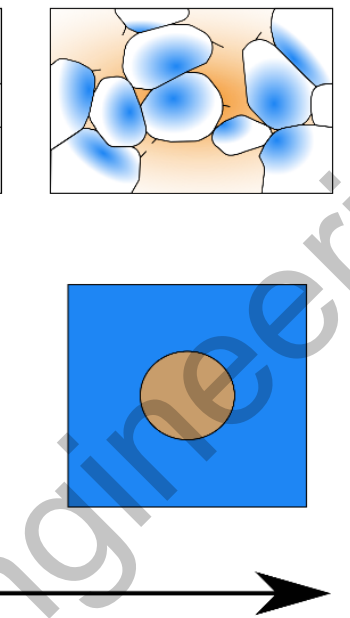

Figure 1. Domain representation at each scale, a) macroscale axisymmetric domain, b) initial cellular structure and its equivalent approximation for the microscale, c) cellular structure and approximation as drying progresses when cell rupturing occurs, and d) cellular structure and approximation as drying progresses after cell rupturing has occurred. 


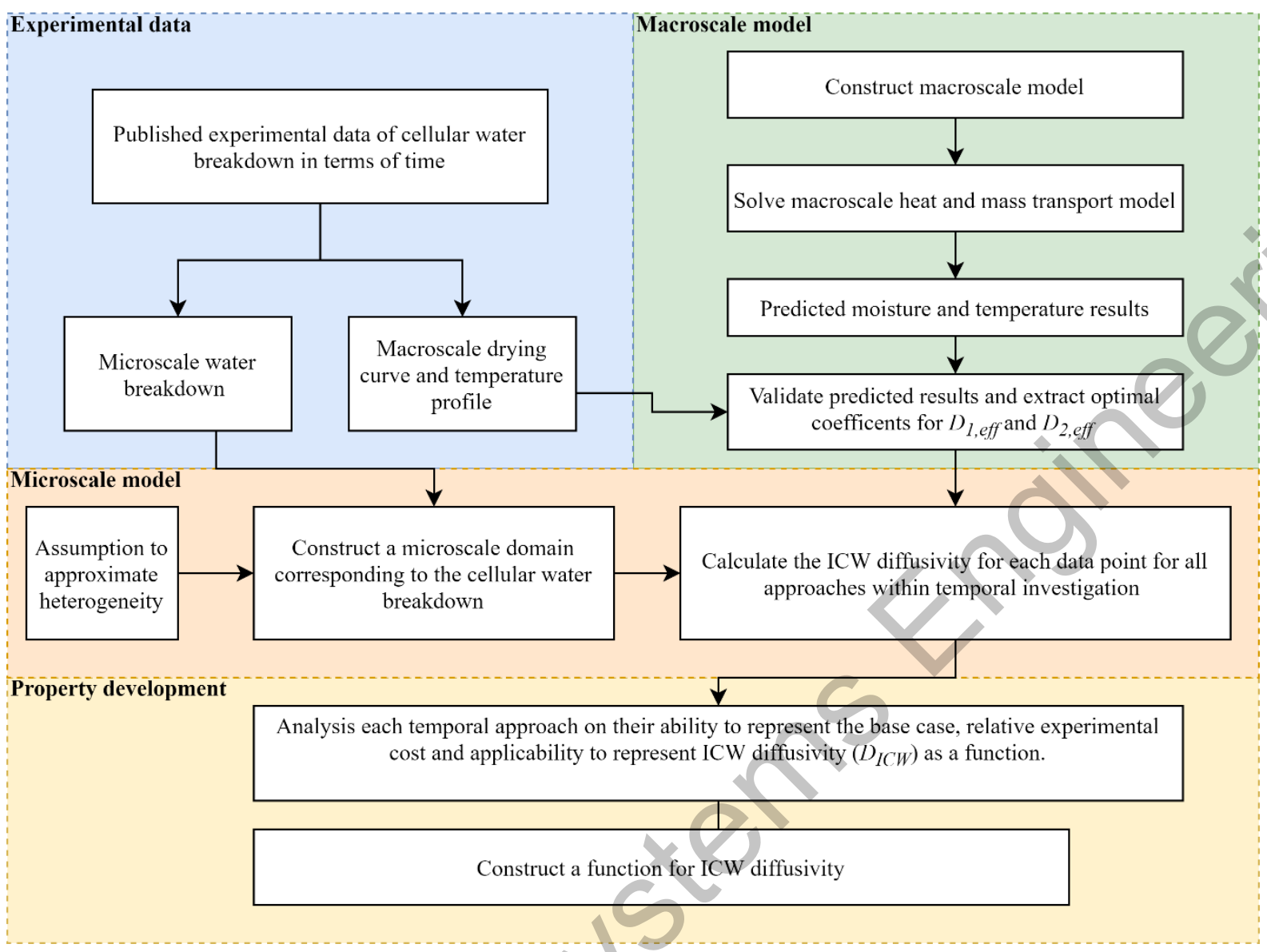

Figure 2. Solution procedure 


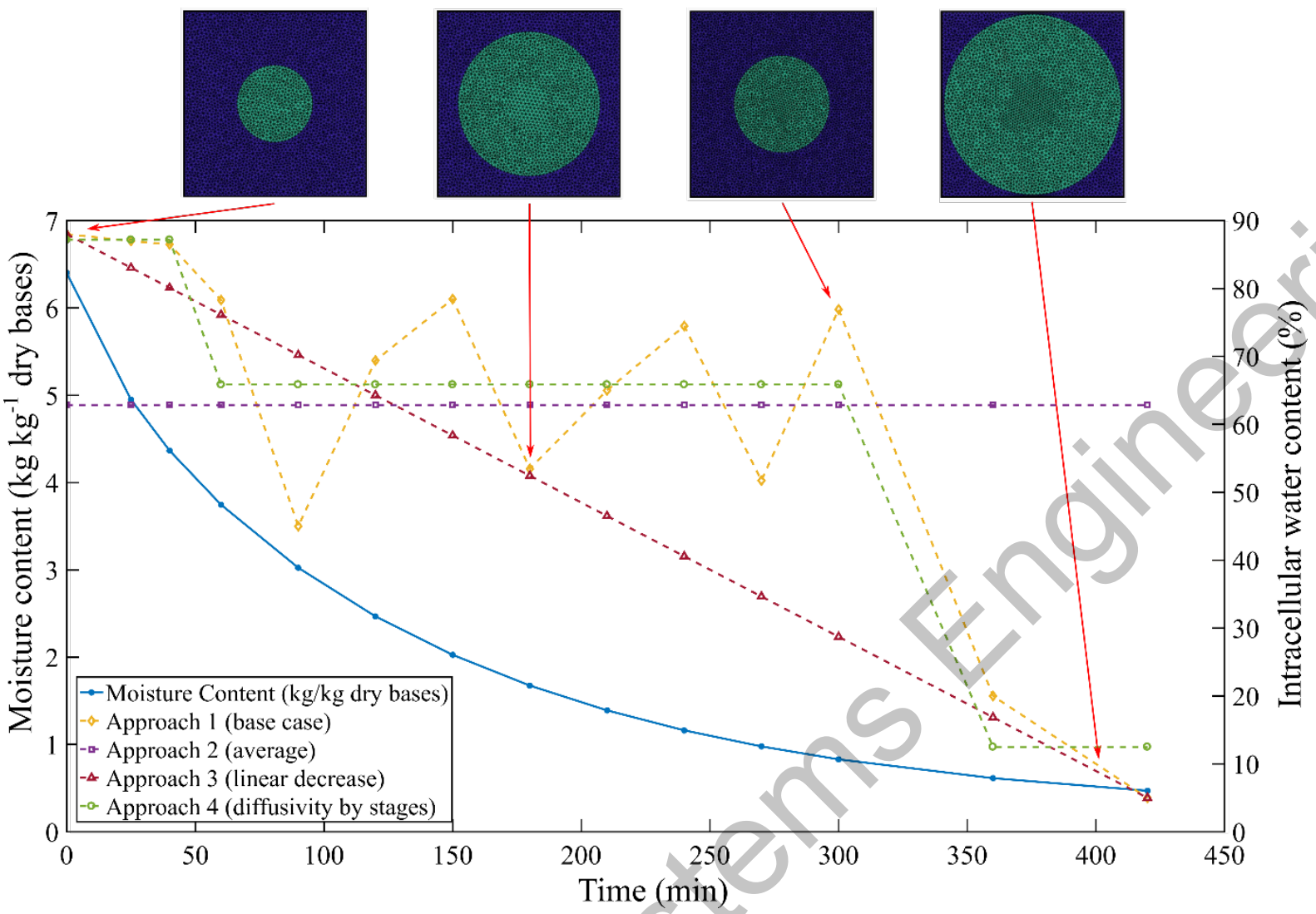

Figure 3. Water heterogeneity breakdown of ICW content and moisture content $\left(\mathrm{kg} \mathrm{kg}^{-1}\right.$ dry bases) with time. Examples of the temporal evolution of the microscale domains can be seen along the top of the figure, purple denotes ICW and green denotes FW. 


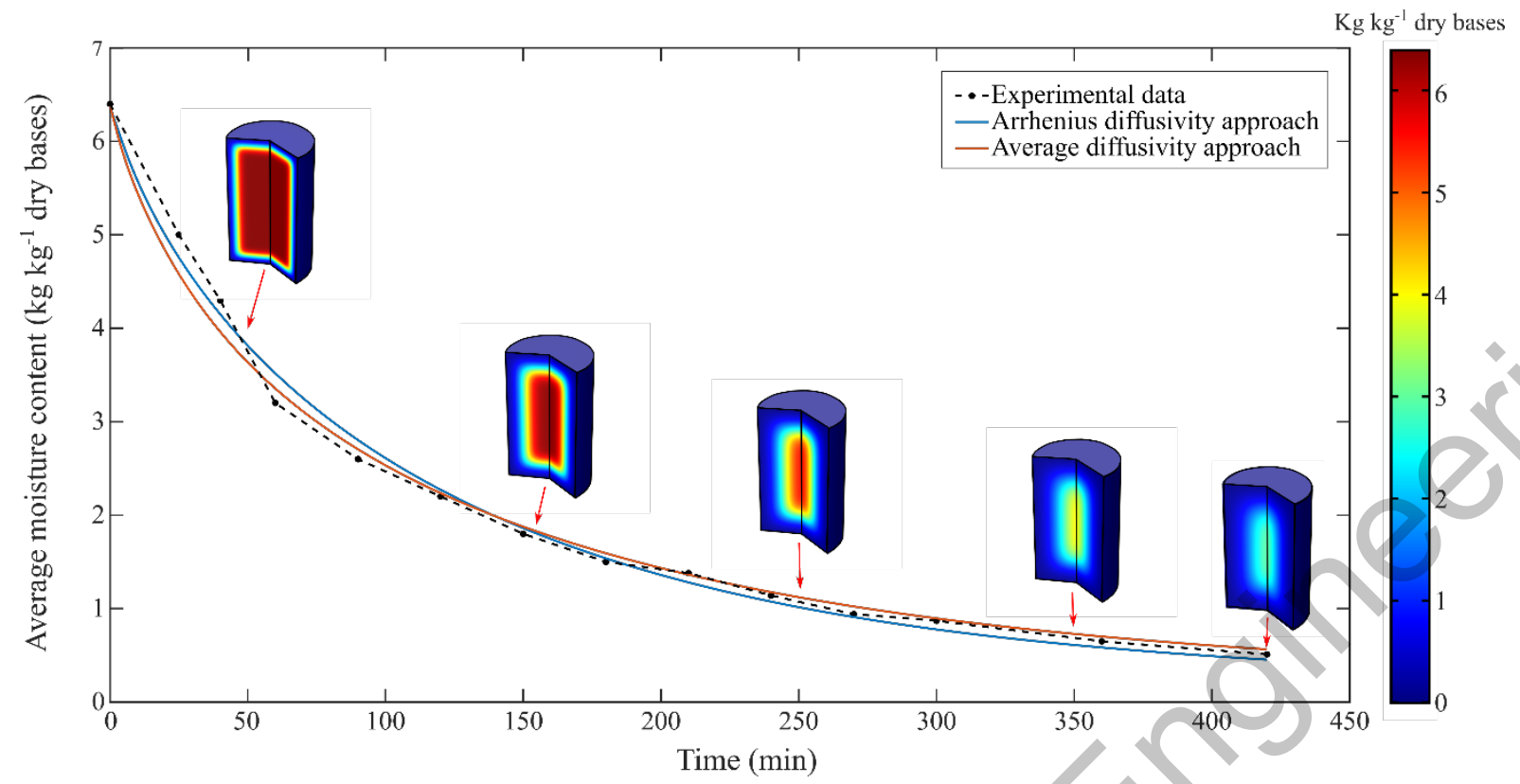

Figure 4. Average moisture content ( $\mathrm{kg} / \mathrm{kg}$ dry bases) for drying at $60^{\circ} \mathrm{C}$. Examples of the samples axisymmetric moisture content profiles are shown for various stages of drying. 


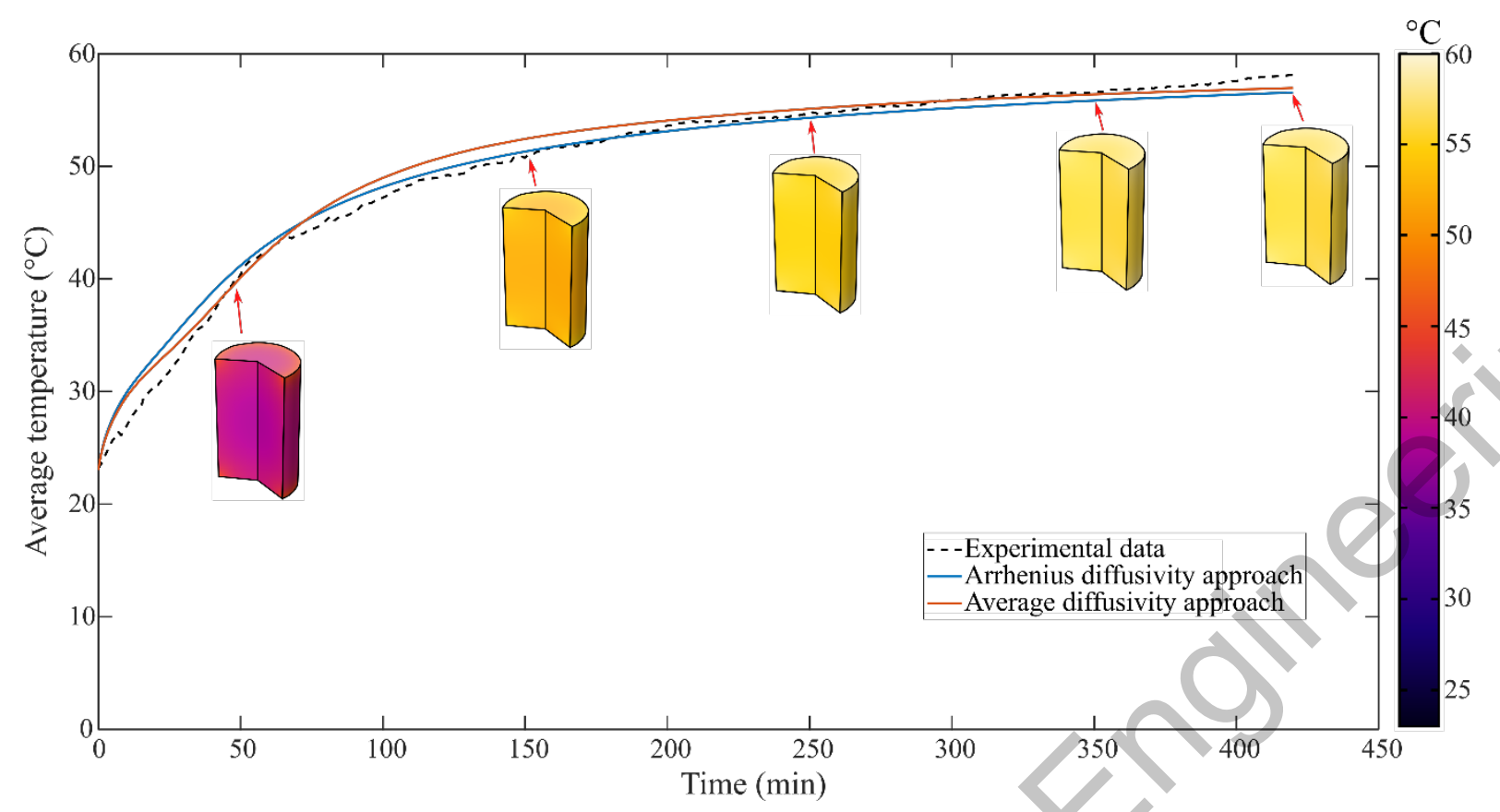

Figure 5. Average temperature $\left({ }^{\circ} \mathrm{C}\right)$ for drying at $60^{\circ} \mathrm{C}$. Examples of the samples axisymmetric temperature profile are shown for various stages of drying. 


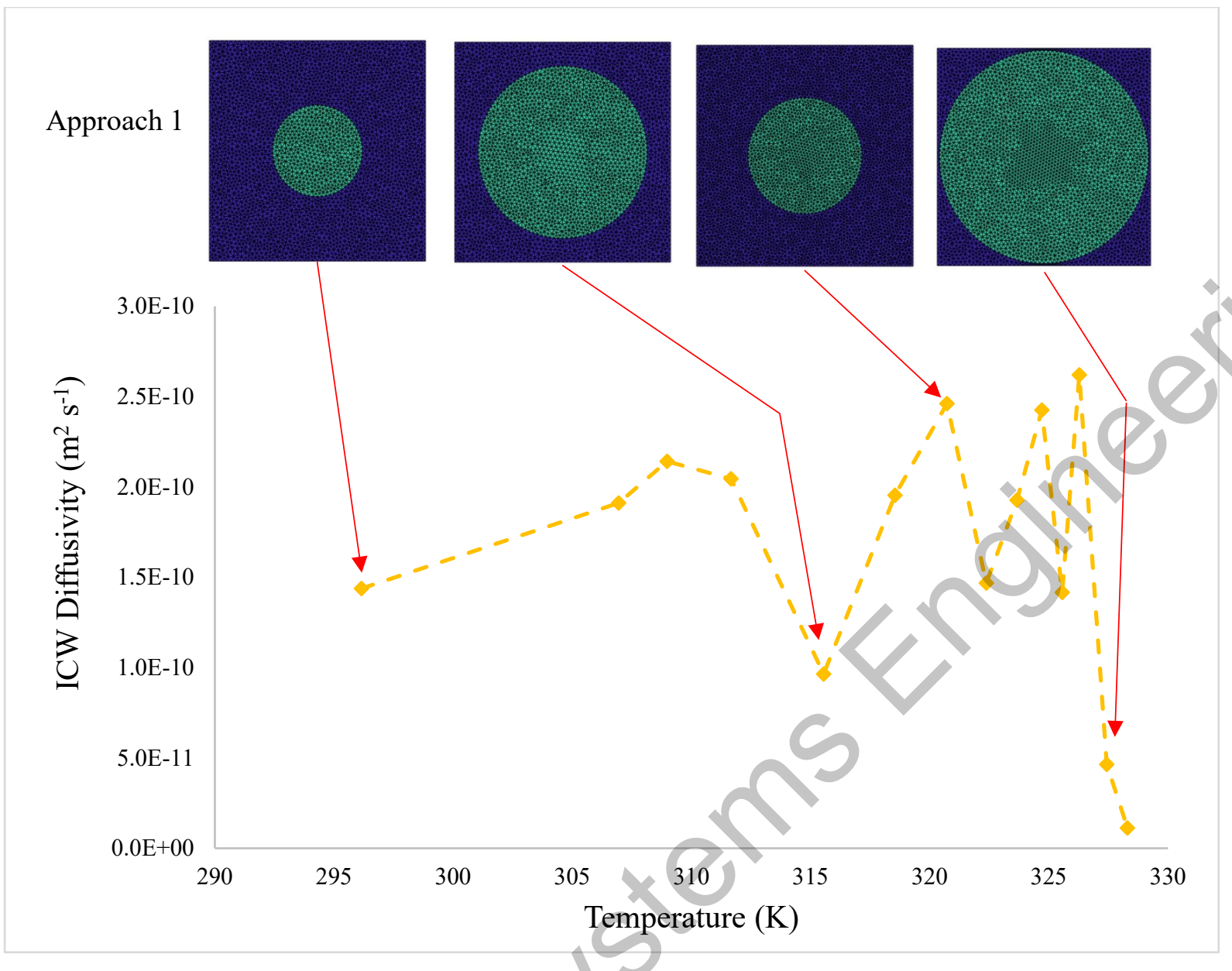

Figure 6. Diffusivity $\left(\mathrm{m}^{2} \mathrm{~s}^{-1}\right)$ of intracellular water for approach 1 (base case). The temporal evolution of the microscale domain can be seen along the top of the figure, purple denotes ICW and green denotes FW. 


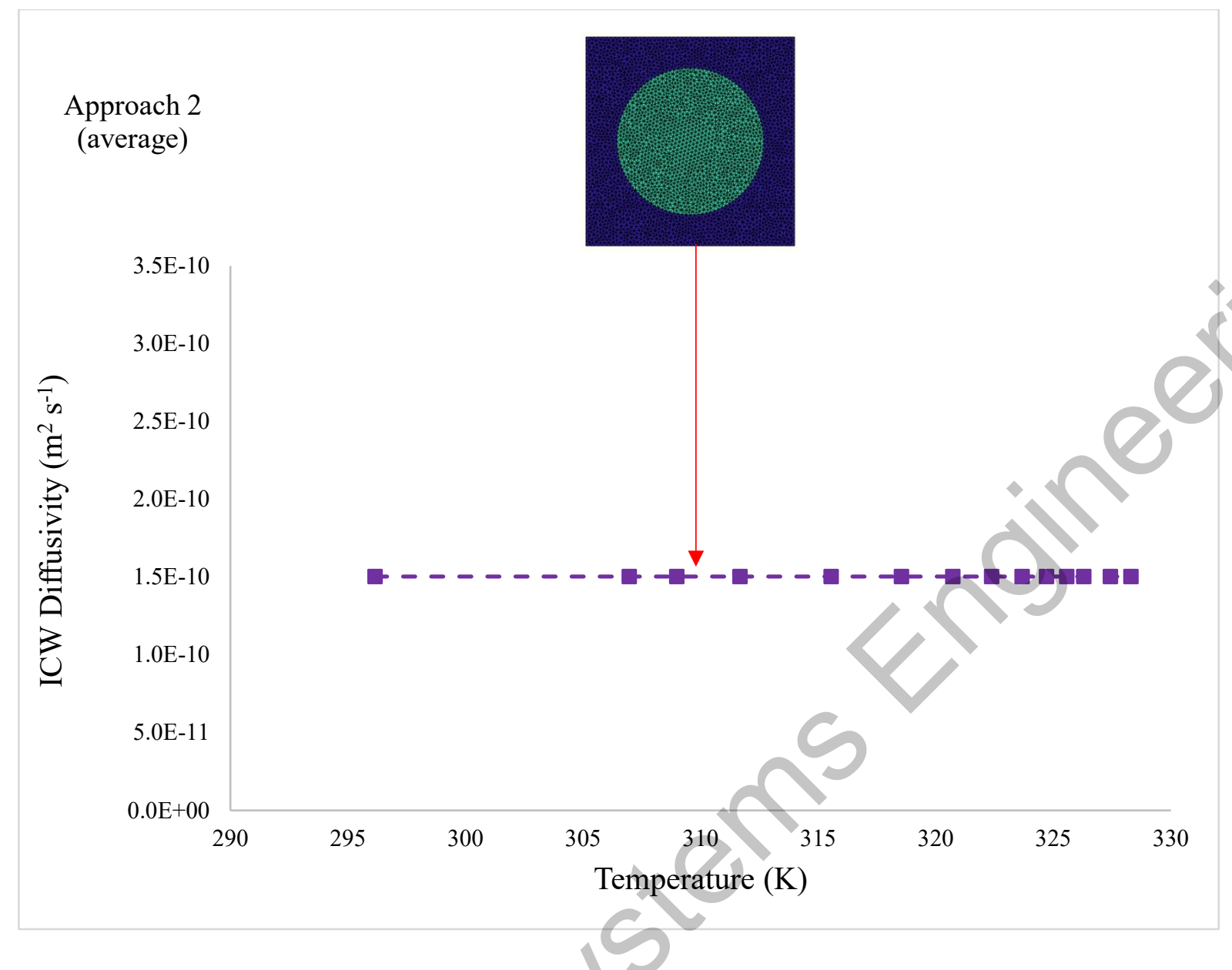

Figure 7. Diffusivity $\left(\mathrm{m}^{2} \mathrm{~s}^{-1}\right)$ of intracellular water for approach 2 (average). The temporal evolution of the microscale domain can be seen along the top of the figure, purple denotes ICW and green denotes FW. 


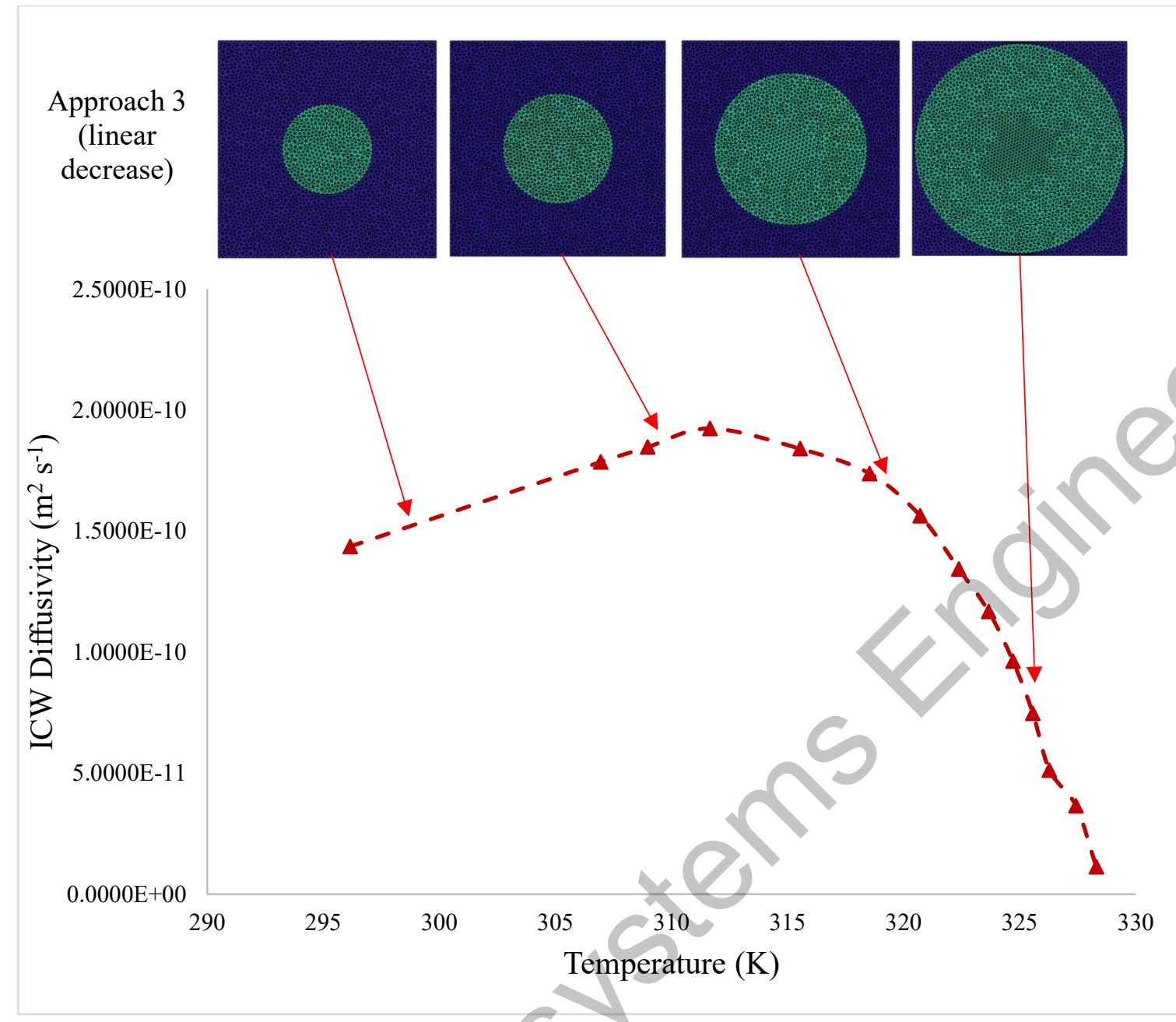

Figure 8. Diffusivity $\left(\mathrm{m}^{2} \mathrm{~s}^{-1}\right)$ of intracellular water for approach 3 (linear decrease). The temporal evolution of the microscale domain can be seen along the top of the figure, purple denotes ICW and green denotes FW. 


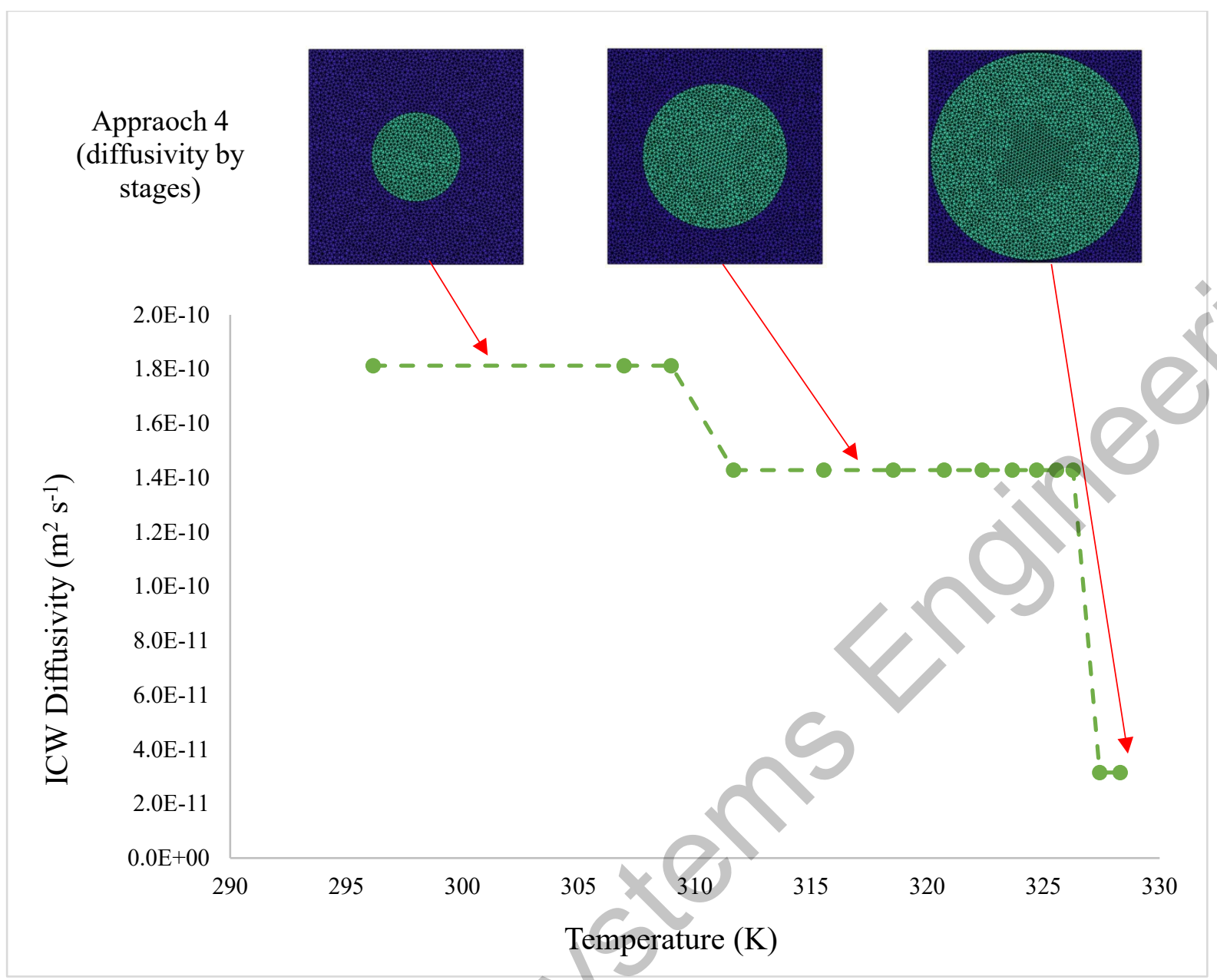

Figure 9. Diffusivity $\left(\mathrm{m}^{2} \mathrm{~s}^{-1}\right)$ of intracellular water for approach 4 (diffusivity by stages). The temporal evolution of the microscale domain can be seen along the top of the figure, purple denotes ICW and green denotes FW. 


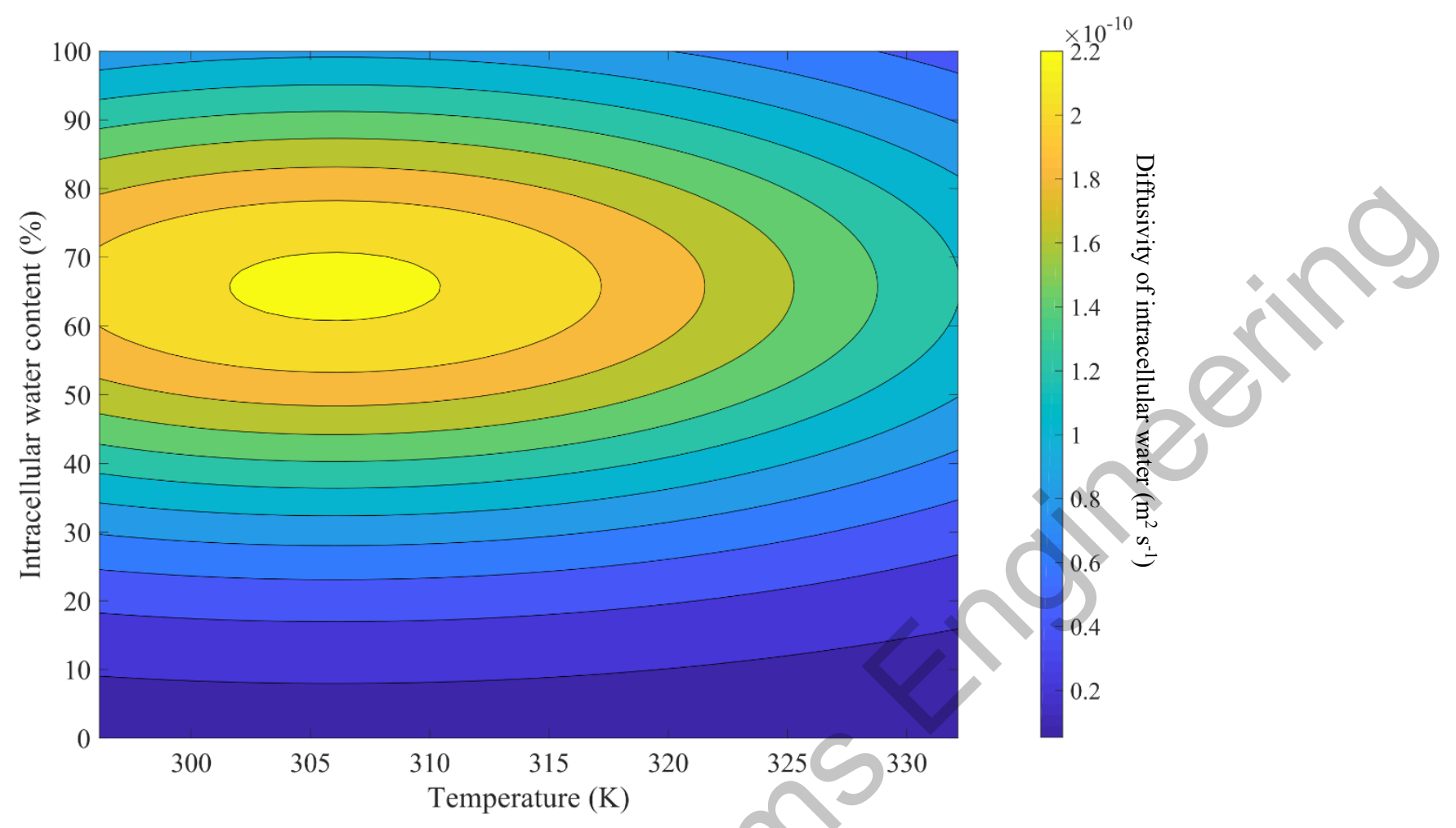

Figure 10. Proposed $D_{I C W}\left(\mathrm{~m}^{2} \mathrm{~s}^{-1}\right)$ function [Equation (19)] in terms of sample temperature (K) and intracellular water content (\%). 